\title{
Petrography, Sedimentology and Geochemistry of Rocks and Sediments from Three Key Localities from the South-East Region of the Yaoundé Group (Centre Region, Cameroon): Implications for Rutile Exploration
}

\author{
Jules Mbanga Nyobe ${ }^{1 *}$, Louise Marie Ngo Bidjeck Bondje ${ }^{1}$, Dieudonné Charles Ilouga², \\ Elisé Sababa1
}

${ }^{1}$ Department of Earth Sciences, University of Yaoundé I, Yaoundé, Cameroon

${ }^{2}$ Higher Teachers Training College, University of Yaoundé I, Yaoundé, Cameroon

Email: *julesnyobe@yahoo.com

How to cite this paper: Nyobe, J.M., Bondje, L.M.N.B., Ilouga, D.C. and Sababa, E. (2021) Petrography, Sedimentology and Geochemistry of Rocks and Sediments from Three Key Localities from the South-East Region of the Yaoundé Group (Centre Region, Cameroon): Implications for Rutile Exploration. International Journal of Geosciences, 12, 714-737. https://doi.org/10.4236/iig.2021.128041

Received: July 26, 2021

Accepted: August 27, 2021

Published: August 30, 2021

Copyright $\odot 2021$ by author(s) and Scientific Research Publishing Inc. This work is licensed under the Creative Commons Attribution International License (CC BY 4.0).

http://creativecommons.org/licenses/by/4.0/

\begin{abstract}
The Otele, Matomb and Nguibassal localities correspond to the SW part of the Yaoundé Group. Field observations, rocks and stream sediments of the study area were examined using rock tin sections, granulometric, morphoscopic and $\mathrm{X}$-ray fluorescence analysis to identify their distribution, the nature of the basement, provenance useful minerals and some weathering process that affect them to show the exploration significance of these outcomes. From these it appears that, three rocks types occur in the areas: gneisses, micaschists and amphibolite, respectively with the following minerals assemblage: (Fks $+\mathrm{Bt}+\mathrm{Qz}+\mathrm{Ky}$ $+\mathrm{Pl}+\mathrm{Msc}+\mathrm{Grt}+\mathrm{Op}),(\mathrm{Bt}+\mathrm{Qz}+\mathrm{Msc}+\mathrm{Fks}+\mathrm{Op}+\mathrm{Ky}+\mathrm{Grt})$ and $(\mathrm{Amp}+$ $\mathrm{Bt}+\mathrm{Pl}+\mathrm{Kfs}+\mathrm{Qz}+\mathrm{Px}+\mathrm{Grt}+\mathrm{Op})$. Sedimentological analyses reveal the dominance of unworn grains of rutile quartz and kyanite that suggest a short transport; while less abundant minor shiny dulls and sub-rounded grains suggest a long transport. Sediments collected are homometric, well sorted, well classified, with immature rutile due to their angular shapes. Silica is the most important major element ranging in concentration between $47.56 \mathrm{wt} \% \mathrm{SiO}_{2}$ in amphibolite to $61.21 \mathrm{wt} \% \mathrm{SiO}_{2}$ in gneiss. Stream sediments chemistry equally showed that silica and alumina are the remarkable elements with values of 53.92 wt $\%$ and $13.33 \mathrm{wt} \%$ respectively with important increase of $\mathrm{TiO}_{2}$ ranging between 51.77 and $95.03 \mathrm{wt} \%$. The $\mathrm{TiO}_{2}$ percentage met in minerals of the global fraction and rutile concentrate come from the same minerals in the rock, and percentage increases when linked to heavy minerals observation suggested the Ti percentage to mainly come from rutile. Impurities present in the rutile
\end{abstract}


lattice include: $\mathrm{V}, \mathrm{Nb}, \mathrm{Ta}, \mathrm{Cr}$ and $\mathrm{CaO}$. Rutile was found to come from the same area but with several source rocks (Felsic and mafic). High Nb contents (277 $768.33 \mathrm{ppm})$ as compared to $\mathrm{Cr}(394-444.33 \mathrm{ppm})$ associated to the elevated ratio of LREE/HREE coupled to the negative Eu anomalies in rocks and sediments of the study area are indicative of felsic source material. Moreover, enrichment in $\mathrm{Cr}$ as compared to $\mathrm{Nb}$ at Nguibassal suggested rutile to originate from mafic rocks.

\section{Keywords}

Rutile, Global Fraction, SW Yaoundé Group, Unworn Grains, Impurities

\section{Introduction}

The SW part of the Yaoundé Group contained several key rutile host areas among which Otele, Nguibassal and Matomb. This Group is characterized by rocks containing kyanite and rutile [1]. Lithologic formations are constituted by a mixture of kyanite-titanite minerals containing variable part of cryptocrystalline to paracrystalline compounds [2] [3] associated to zircon [4]. Prospected zones in the Yaoundé Group are limited but geochemical characteristics are similar from one sector to another. The source of heavy metals in the listed key zones, particularly for rutile is subject to several hypotheses. Some works (e.g. [1] [5]) envisaged local deposits and indicated that sources were probably in the Yaoundé Group. However, according to [4], the minerals could have been issued from metamorphic formations, and their distribution being assured by the various nearby water courses. Moreover, [4] proposed a supply from local sources, because prospection in the watershed of Lobo, NW of the Yaoundé Group has revealed considerable concentration of rutile in alluviums and in nearby rocks. According to this author, a great part of the alluvial material of this sector has been probably furnished by the metamorphic rocks in place. They further suggest that, the rocks in place could have concentrated rutile at the time of their formation and dismantling.

Deciphering these assertions could be of great importance when it comes to rutile exploration in the Yaoundé Group. The validity of these proposed hypotheses can be tested by petrographic, sedimentologic and geochemical study of materials from these three key areas of the SW of Yaoundé Group. The aim of this study is to characterize rocks and mainly sediments in order to rutile exploration in the study area.

\section{Geographical and Geological Setting}

The Otele, Nguibassal and Matomb areas are located in the Center Region of Cameroon, in the Nyong and Kelle Division as well as a small part of the Mefou and Akono Division, in the central region of Cameroon. It lies between the parallels $3^{\circ} 36^{\prime} 15^{\prime \prime}$ to $4^{\circ} 2^{\prime} 56^{\prime \prime}$ North and meridians $11^{\circ} 2^{\prime} 10^{\prime \prime}$ to $11^{\circ} 17^{\prime} 37^{\prime \prime}$ East (Figure 1 ). 


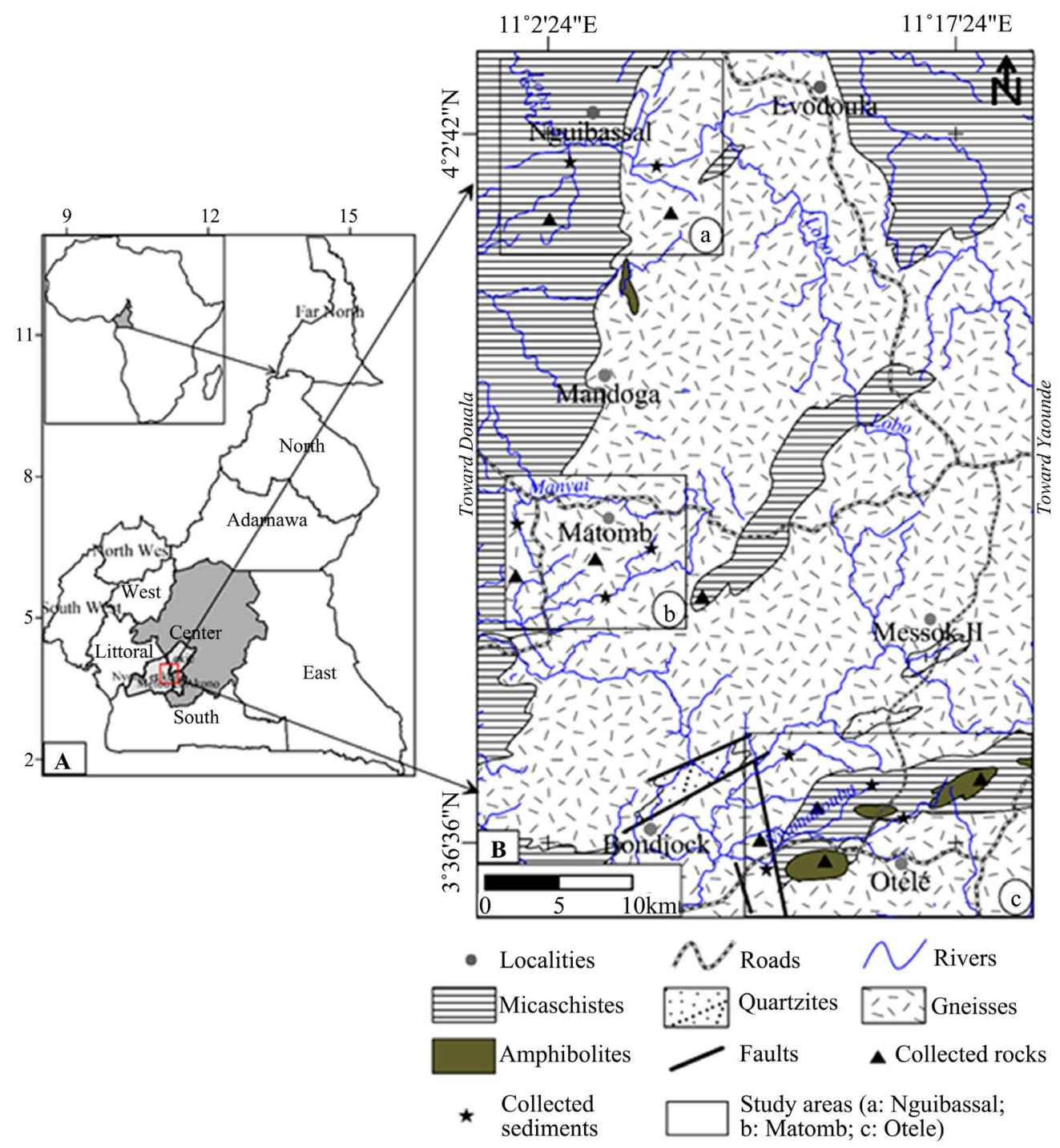

Figure 1. Location map of the study area in the central region of Cameroon [1].

According to the Eseka climatic data close to the study area, the climate is of equatorial type with four seasons and it belongs to the dense humid forest domain, characterized by a dominant step of raised trees and a lower floor or sub-wood formed of trees and of rare herbaceous plants [6]. The area belongs to two watersheds: the Sanaga at Lobo and the Nyong at Teba and Nyamakouba with a dendritic hydrographic network.

The study areas are included in the Yaoundé Group, which is an allochthonous unit emplaced onto the Congo Craton that constitutes a part of the Central African Mobile Zone (CAMZ) [1] [7] [8]. Two great geological formations underlie South Cameroon within the CAMZ. The basement constituted of metamorphic rocks (gneisses, quartzites and schists) and the Yaoundé Group that comprises the Mbalmayo-Bengbis-Ayos series and the Yaoundé series [9]. The occurrence of rutile and kyanite in the East and West of Yaoundé Group is known in gneisses and micaschists since the last century. 


\section{Methodology}

\subsection{Field Methods}

Geological fieldwork mainly involved sampling, with a total of 36 samples representing the various lithologies of the study area collected in the field. In addition, $1.5 \mathrm{~kg}$ of stream sediment samples were collected in each sampling point of the three main locations, with four at Otele (Nyk1p, NykIIv, Nyk2, and SOP1) in the Nyamakouba watershed, two at Nguibassal (MBE, and MBA) in the Lobo watershed and three at Matomb (VRO1, VRO2, and MTC) in the Teba watershed, panned in situ during the river alluvial survey.

\subsection{Laboratory Methods}

A total of 16 samples from three locations were collected in the field, including 8 rock types among which: gneisses (KA1, NK2, GE2, and Ml), amphibolites (NKD1 and NKD2) and micaschists (RM, Li); alongside 8 stream sediments samples with the global fraction (SOP1, VSO1, and VSO2) and the concentrate (MBE, MBA, and MTC).

Representative rocks outcropping in the area devoid of any visible secondary alteration were selected, with thin sections done and investigated at the Institute of Mining and Geological Research of Nkolbisson (Cameroon).

The global fraction of stream sediments was collected and lager clasts removed with the sieve of mesh $5 \mathrm{~mm}$. The sediment concentrates were also prepared after washing the sample in a pan and shaking it sideways. Thus, heavy minerals could be found at the bottom.

Scanning separation of pre-concentrated heavy minerals of stream sediments were done at Otele, in two localities (Mabando and Nkolmelen) on four points, at Nguibassal on two points and Matomb on three points (Figure 1). All the collected stream sediment samples were dried in an oven, and then split to obtain two samples of $750 \mathrm{~g}$ each. They were then subjected to sedimentological analysis, including: granulometric analysis (sieving with a standardized AFNOR sieve column using the methods of [10] and [11]. The limits of sorting used are those of [12], while the asymmetric coefficient was interpreted as per [13].

Heavy mineral separation was done using the fraction between $2 \mathrm{~mm}$ and 0.125 $\mathrm{mm}$ at Otele and $1 \mathrm{~mm}$ and $0.125 \mathrm{~mm}$ at Matomb and Nguibassal to determine the heavy minerals associated to rutile in the sediments, and morphoscopic analyses of rutile, quartz and kyanite minerals observation in the fraction between 2 $\mathrm{mm}$ and $0.125 \mathrm{~mm}$ were performed using a binocular microscope.

Eight representative rocks samples, the global fraction and the concentrate of sediment were chosen for whole-rock geochemical analyses. The bulk samples were initially reduced in a jaw crusher and then manually fine powdered in agate mortars to avoid any contamination.

Major oxides were analyzed using a Phillips MagiX PRO Model 2440 X-ray fluorescence (XRF) spectrometer provided with suitable software SUPER Q 3.0, at 
the CSIR-National Geophysical Research Institute Hyderabad. SUPER Q 3.0 is a software package integrated with other analytical instruments that makes the spectrometer accessible to administrators and routine operators with minimal training time. It generates optimized analysis programs for the elements to be measured. These programs allow the standardization of analysis methods within a company. Pressed pellets of the representative samples and geochemical reference materials were prepared separately and loaded into XRF for analysis. Pressed pellets preparation involved weighing two grams on finely powdered (200 mesh ASTM) sample/standard in collapsible aluminum cups filled at the bottom with $2.5 \mathrm{~g}$ of boric acid, later pressed under a hydraulic pressure of $25 t$ to obtain the pellet. International rock reference materials from Japan, Canada, France and National Geophysical Research Institute (India) were used to calibrate the instrument and to check the accuracy of analytical data. The precision and accuracy of the analysis was $<2 \mathrm{wt} \% \mathrm{RSD}$ for almost all the major oxides.

For trace elements including rare earth elements (REE) and high field strength elements (HFSE), the homogenized sample powder was dissolved in reagent grade $\mathrm{HF}: \mathrm{HNO}_{3}$ acid mixture in Savillex screw top vessels. A test $(0.05 \mathrm{~g})$ of sample was added to $25 \mathrm{ml}$ Savillex Teflon pressure decomposition vessels. To each sample, $10 \mathrm{ml}$ of an acid mixture (containing 7:3:2 $\mathrm{HF}^{-} \mathrm{HNO}_{3}-\mathrm{HCl}$ ) was added. Subsequently, $5 \mathrm{ml}$ of $1 \mathrm{ng} / \mathrm{ml} \mathrm{103Rh} \mathrm{solution} \mathrm{was} \mathrm{added} \mathrm{as} \mathrm{an} \mathrm{internal} \mathrm{standard} \mathrm{to} \mathrm{each} \mathrm{Sa-}$ villex vessel. After thorough swirling, the vessels were tightly closed and kept on a hot plate at $\sim 140^{\circ} \mathrm{C}$ for $48 \mathrm{~h}$. Following this, the vessels were opened and the contents were evaporated at $200^{\circ} \mathrm{C}$ to near dryness with, a few drops of $\mathrm{HClO}_{4}$ to ensure complete removal of $\mathrm{HF}$ and $\mathrm{HCl}$ from the mixture. The remaining residues were dissolved by adding $10 \mathrm{ml}$ of $1.1 \mathrm{HNO}_{3}$ and the volume we made to $250 \mathrm{ml}$ with Milli Q de-ionized water (18 M $\Omega$ ) and the solution was stored finally in HDPE tolls. Matrixes matching certified reference materials JG-2, JG-3, JB-2 from geological survey of Japan and G-1A, G-2 from USGS along with couple of procedural banks were also prepared with the sample batch by adopting the same protocol described above to neglect errors due to reagent and handing. In the present investigation, very clear solutions were obtained for all the samples and calibration standard. Solutions were analyzed by PerkinElmer ${ }^{\circledR}$ Model ELAN DRC $^{\text {TM }}$ II ICP mass spectrometer (PerkinElmer, Inc, Shelton, CT, USA) at the CSIR-National Geophysical Research Institute (NGRI), Hyderabad, India. The sample introduction consisted of a standard Meinhard nebulizer with a cyclonic spray chamber. All quantitative measurements were performed using the instrument software (ELAN v. 3.1). This software uses knowledge-driven routines in combination with numerical calculations (quantitative was used as an internal standard and external drift was corrected by repeated analyses of 1.5000 solutions of JG-2, JG-3 and JB-2, which were also used as calibration standards accordingly. Instrument response was corroborated to two independent digestions of G-1 and G-2. Precision and accuracy are better than RSD 5\% for the majority of trace elements. 


\section{Results}

\subsection{Petrography}

Petrographic studies reveal that, the study area is made up of three distinct metamorphic rocks namely gneisses, micaschists and amphibolites. These rocks outcrop as blocks and as paved surfaces. The distribution and dispersion of the different lithological units are shown in (Figure 2). Detail observations were carried out by mapping and description are documented here.

\subsubsection{Gneisses}

They are the most wide-spread rocks of the study area. Gneisses crop out as blocks, boulders and slab. Their foliation is defined by alternating dark mafic and clear quartzo-feldspathic bands (Figure 2(A)). The dark mafic bands are composed
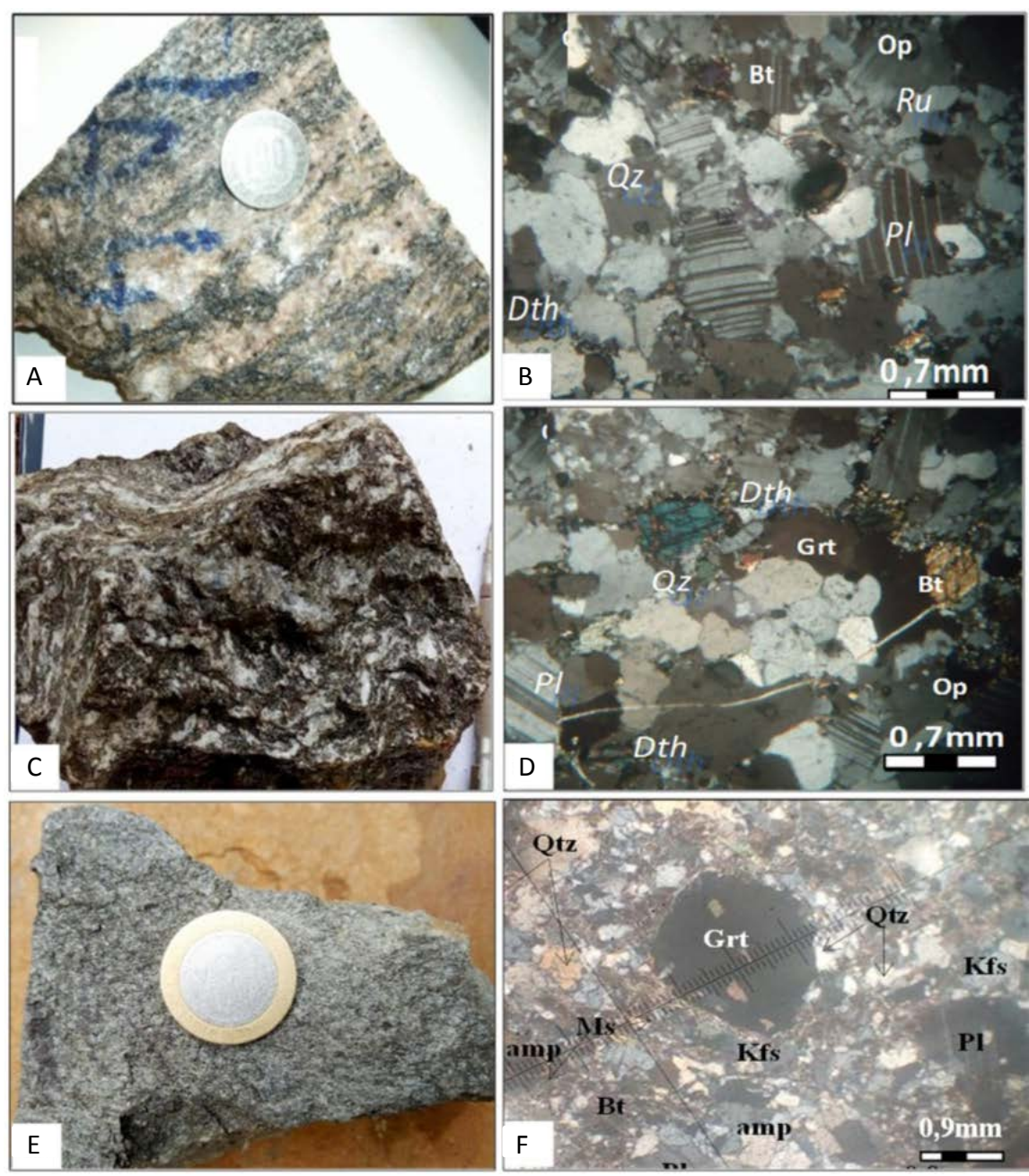

Figure 2. Macroscopic and microscopic view of gneisse, micaschists, and amphibolites of the study area (A) Gneisses showing alteration of dark mafic and white quartzofeldspatic band; (B) Photomicroph showing gneiss paragenesis; (C) Encounvered schistosity micaschist hand specimen; (D) Microphotographic showing micaschist paragenesis; (E) Field photo of amphibolites with abundant white quartz overprinting; (F) Microphotographs displaying amphibolite paragenesis. 
of biotite, garnet, and opaque minerals, while the clear bands are composed of quartz and feldspars. Microscopic scale observation showed a granoblastic heterogranular texture and mineral assemblage constituted of quartz $40 \%-50 \%$, plagioclase $15 \%-20 \%$, alkaline feldspar $10 \%-15 \%$, biotite $5 \%-10 \%$, kyanite $1 \%$ $7 \%$, muscovite $3 \%-5 \%$, garnet $<10 \%$, rutile $1 \%-5 \%$, and the other opaque minerals less than $10 \%$ (Figure 2(B)). Abundant biotite flakes of up to $0.12 \mathrm{~mm}$ that are observed within the rock texture, with some showing the transformation into muscovite.

\subsubsection{Micaschists}

They mainly occur at Matomb and Otele, and are crosscut by quartz lode rich in kyanite. Some blocks of quartzite are also associated. In general, the rock is dark grey in colour and biotite exhibits a local schistosity (Figure 2(C)). Under microscope, the textures that characterize micaschists include granoblastic, lepidoblastic heterogranular. The main minerals are: quartz (35\% - 40\%), Biotite (25\%), plagioclase $(15 \%-20 \%)$, Muscovite $(10 \%-15 \%)$, alkaline feldspar $(7 \%$ $10 \%)$, secondary minerals include opaque minerals (5\%), and garnet (4\%) and kyanite (4\%) (Figure 2(D)). Kyanite forms sky-blue porphyroblast of bladed habit which lie parallel to the foliation. Garnet is ovoid with length that could be up to $1 \mathrm{~mm}$.

\subsubsection{Amphibolites}

They are the least abundant rock types in the study area. They crop out at Otele area (Figure 2). They are greenish with abundant white quartz overprinting, and are composed of quartz, amphibole slate, feldspar, muscovite, garnet and pyrite (Figure 2(E)).

Microscopic observations show a granoblastic heterogranular texture and mineral composition with amphibole quartz (20\% - 25\%), biotite (20\%), plagioclase (15\%), alkaline feldspar (15\%), pyroxene (10\%), muscovite (7\%), garnet (7\%), and opaque minerals (4\%) (Figure 2(F)).

\subsection{Sedimentological Analysis}

Macroscopic observation of sediments showed that they are mainly composed of quartz, rutile, kyanite, and opaque minerals. Cumulative curve plotted obtained from granulometric analysis showed a steep to medium slope in the $S$ form that is slightly truncated at the bottom and in tiers (Figure 3). Quartiles Q1, Q2, Q3 respectively representing $25 \%, 50 \%$, and $75 \%$ of the sediments obtained from this curve permit to calculate the Krumbein deviation Quartile $(\mathrm{Qdphi}=(\mathrm{Q} 1 \times \mathrm{Q} 3) / 2)$, the Track sorting index $\left(\mathrm{So}=(\mathrm{Q} 1 / \mathrm{Q} 3)^{1 / 2}\right)$, and the asymmetric coefficient $(\mathrm{AS}=$ $\left.\mathrm{Q} 1 \times \mathrm{Q} 3 /(\mathrm{Q} 2)^{2}\right)($ Table 1$)$. These results showed that, the Krumbein coefficient is between 0.11 and 0.22 ; the sorting index from 0.44 to 1.54 and the asymmetric coefficient from 0.96 to 1.27 (Table 1 ).

Data obtained permit to conclude that, the sediments of the three locations of the Yaoundé Group are well sorted, well classified and composed of fine grains 
Frequency (\%)

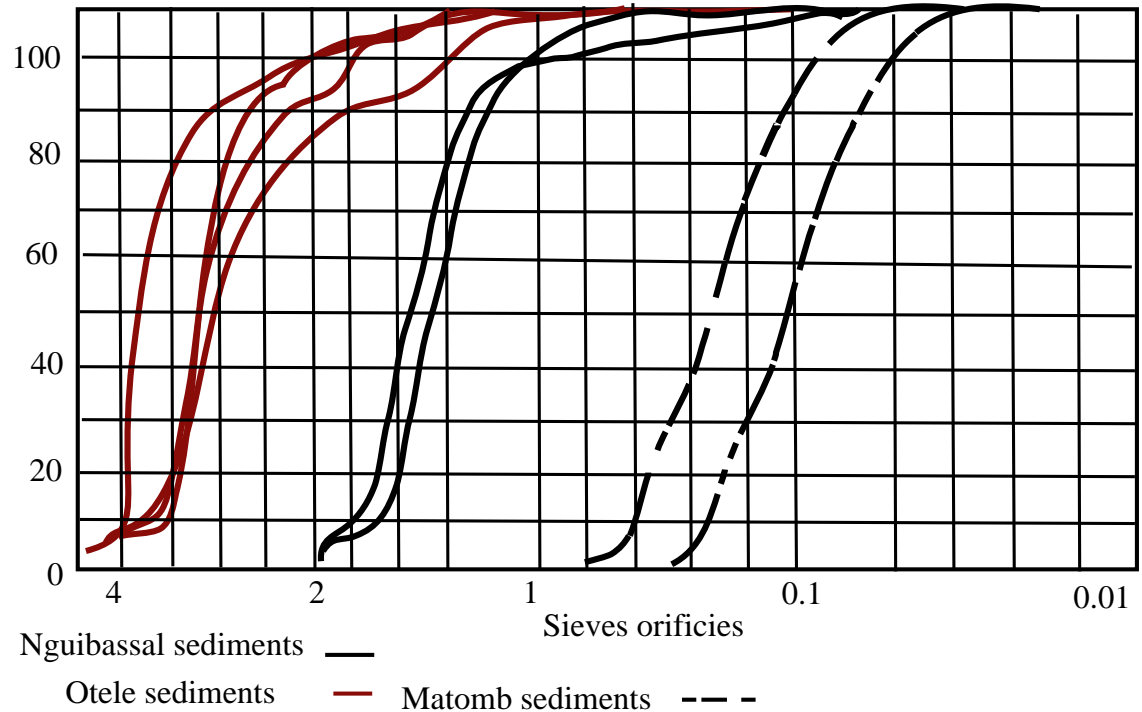

Figure 3. Cumulative curves showing well sorted and classified grains at all site.

Table 1. Summary of the various granulometric parameters.

\begin{tabular}{cccc}
\hline & Otelé & Matomb & Nguibassal \\
\hline Q1 & 0.25 & 0.31 & 0.30 \\
Q2 & 0.47 & 0.55 & 0.58 \\
Q3 & 0.85 & 1.1 & 1.50 \\
Qdphi & 0.11 & 0.17 & 0.22 \\
So & 0.80 & 1.88 & 2.23 \\
As & 0.96 & 1.28 & 1.4 \\
\hline
\end{tabular}

at Nguibassal, medium to coarse grains at Matomb and Otele. Therefore, these sediments are homometric, well sorted and well classified.

In general, heavy mineral assemblage encountered in the three locations studied included the following mineral association: kyanite, rutile, brookite, zircon, andalusite, muscovite, apatite, garnet and tourmaline, and opaque minerals. Their shape mainly showed angular to sub-angular shape and very few sub-round grains (Figures 4(A)-(F)). Minerals such as staurolite sillimanite of minor importance were observed at Otele area. Relative abundance of heavy minerals in both global fraction and concentrate showed kyanite and rutile as the most recurrent minerals. Zircon is highly observed at Nguibassal area.

\subsection{Morphoscophic Analysis}

Morphoscopic studies on 981 grains of quartz, rutile and kyanite grains showed that, the grains are unworn, sub-blunt and shiny blunt (Figures 5(A)-(E)). Statistical counting of these grains reveals that, about 634 are unworn (approximately $64.62 \%), 195$ are sub-blunt (19.87\%), while 80 are shiny blunted grains $(8.15 \%)$ 

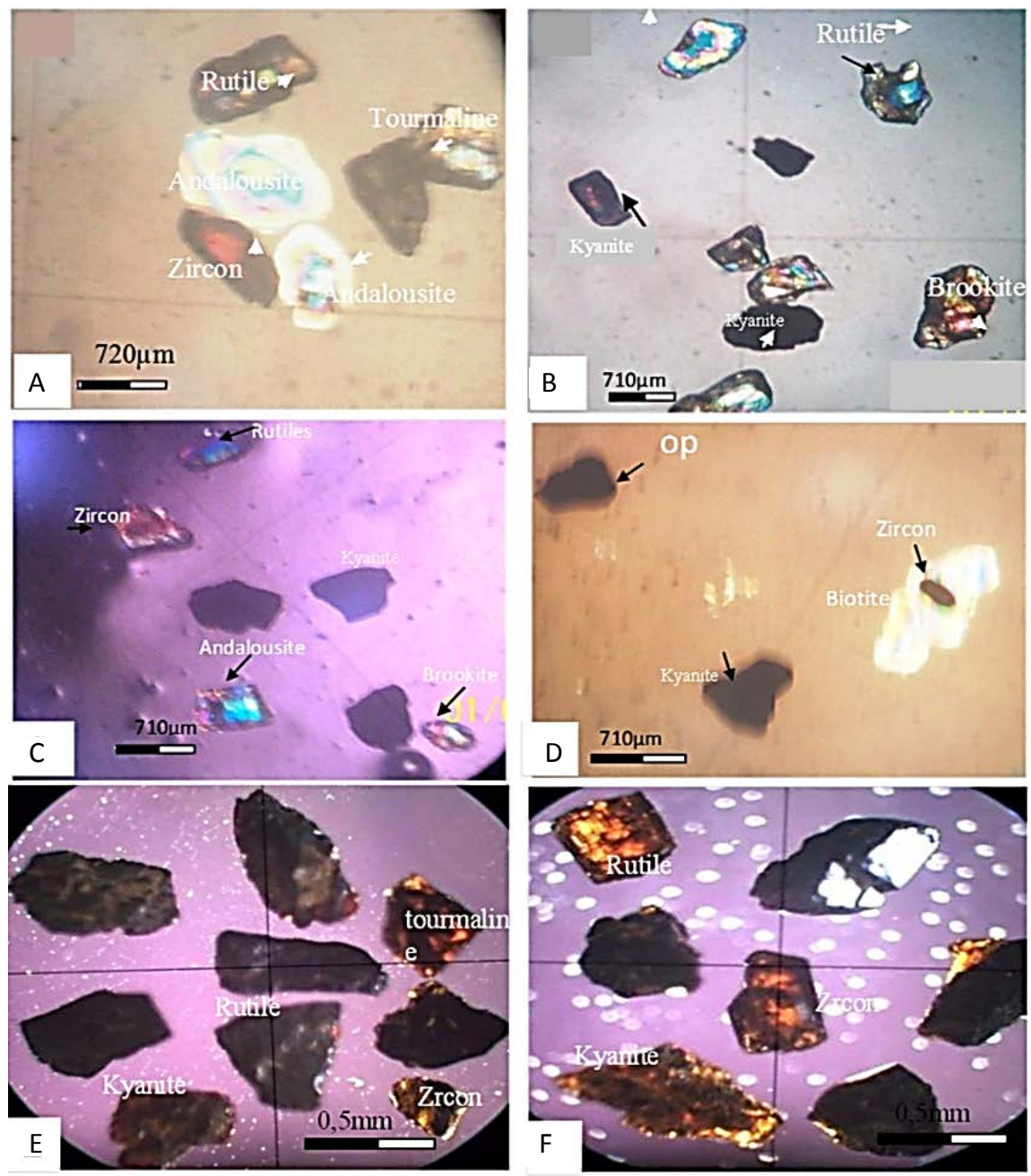

Figure 4. Heavy minerals of the area of study (A, B) Otelé area, (C, D) Matomb area, (E, F) Nguibassal area.

and the less significant sub-round grains $(0.10 \%)$, showing a significant conflict throughout their transport under the effect of dynamic forces from where a distant origin (Table 2). The unworn grains with their angular shape indicate immature sediment that result from short transportation in the three locations of the study area. The less abundant sub-blunt would come from a more or less long transport by fluvial waters. Shiny blunted grains are characteristic of long transport in continental aquatic environments (rivers). Representation of these three minerals in global fraction showed a dominance of unworn grains in sediments. The total population therefore exhibits angular to sub-angular with a dominance of angular forms.

Alluvial rutile study varies from very coarse sand to fine sand in the Wentworth 1922 clastic particles size classification (from $2 \mathrm{~mm}$ to $0.125 \mathrm{~mm}$ ). At Otele and Matomb areas, the grains seize is generally above $0.5 \mathrm{~mm}$ while rutile at Nguibassal area is smaller. They are black greyish, opaque with metallic luster and form subhedral crystals. Their shape appears as tabular or elongated with angular 

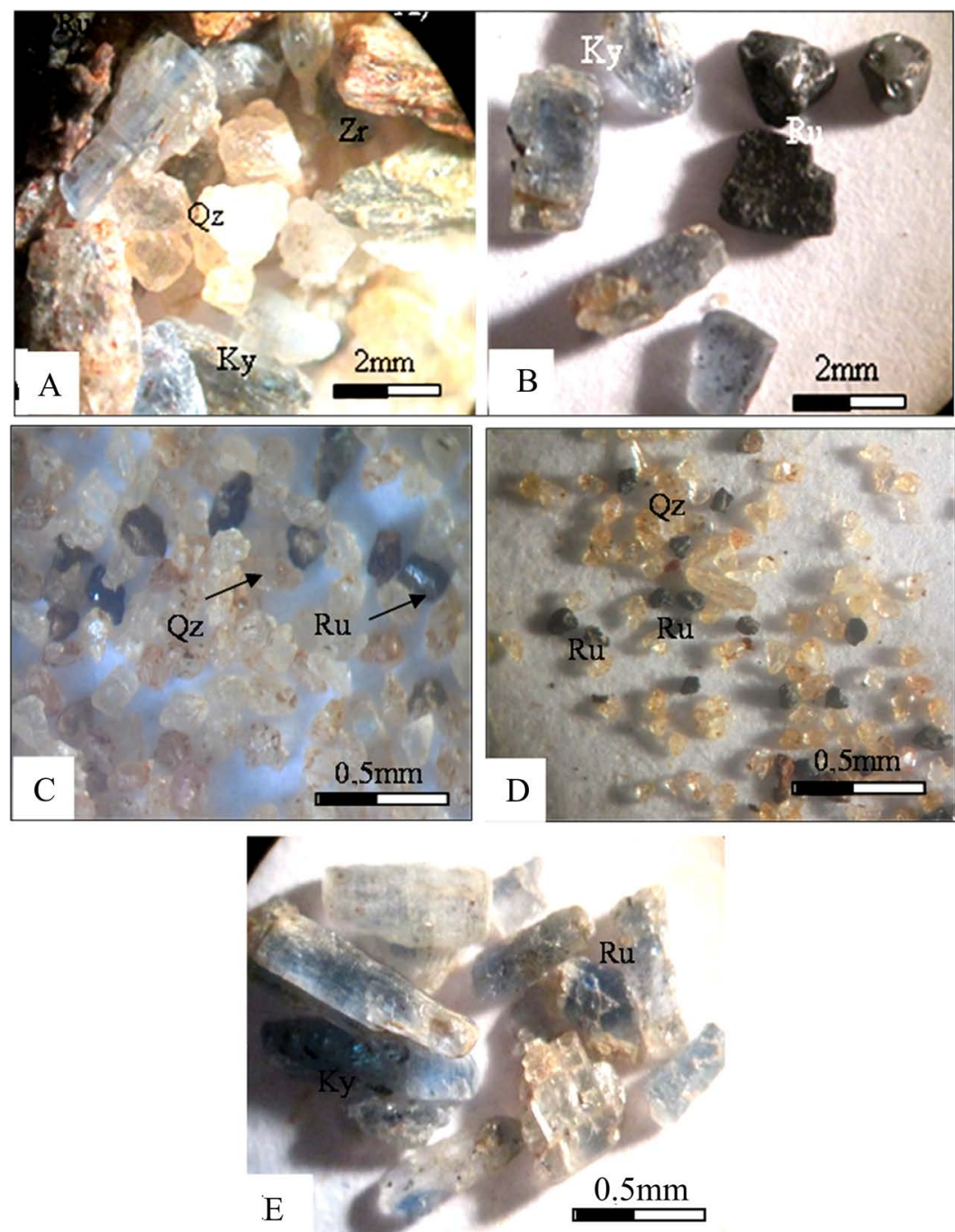

Figure 5. Sediments morphology in the study area (A, B, C, D and E) (A) Unwons grains of kyanite, quartz and rutile alongside some shiny blunt quartz grains; (B) Sub blunt grains of rutile and elongated and rhombohedral kyanite; $(C, D, E)$ Rutile concentrate with angular and sub-angular form.

Table 2. Habit and shapes of grains in the statistical counting of global sediment concentrate.

\begin{tabular}{|c|c|c|c|c|c|c|c|c|c|c|c|}
\hline \multirow{3}{*}{ Locaton } & \multicolumn{11}{|c|}{ Habit and shapes of grains } \\
\hline & \multirow{2}{*}{ Granulometric intervals } & \multicolumn{3}{|c|}{ Unworm grains } & \multicolumn{3}{|c|}{ Sub-blunt grains } & \multicolumn{3}{|c|}{ Shinyblunt grains } & \multirow[t]{2}{*}{ Rounds mat } \\
\hline & & Rutile & Quartz & Kyante & Rutile & Quartz & Kyante & Rutile & Quartz & Kyante & \\
\hline & $1-0.5 \mathrm{~mm}$ & 88 & 70 & 66 & 23 & 18 & 17 & 6 & 4 & 4 & - \\
\hline \multirow[t]{2}{*}{ Oélé } & $0.5-0.125 \mathrm{~mm}$ & 72 & 57 & 54 & 20 & 16 & 15 & 5 & 4 & 3 & - \\
\hline & $1-0.5 \mathrm{~mm}$ & 28 & 13 & 12 & 17 & 3 & 3 & 15 & 2 & 2 & 1 \\
\hline \multirow[t]{2}{*}{ Gubassal } & $0.5-0.125 \mathrm{~mm}$ & 29 & 11 & 11 & 16 & 2 & 2 & 14 & 2 & 2 & - \\
\hline & $1-0.5 \mathrm{~mm}$ & 24 & 7 & 6 & 14 & 2 & 2 & 13 & 1 & & - \\
\hline Matomb & $0.5-0.125 \mathrm{~mm}$ & 50 & 31 & 29 & 26 & 12 & 11 & 18 & 5 & 4 & - \\
\hline TOTAL & - & 291 & 189 & 178 & 116 & 53 & 50 & 71 & 18 & 15 & 1 \\
\hline
\end{tabular}


to sub-angular borders dominant and very few are sub-round with sub-blunt borders.

Granulometric interval investigation of rutile encountered in the three locations of the study area showed that: from the four sampling points of Otele, SOP display $48.72 \%$ of total rutile grains and $51.38 \%$ was obtained in the remaining three sampling points (Nyk1p, NykIIv, and Nyk2) with equal repartition of rutile grains in intervals. The two sampling points of Matomb exhibit equal amount of rutile in the two samples and intervals; Nguibassal showed abundant rutile grains in the fraction between $0.5-0.125 \mathrm{~mm}$ (Table 3).

\subsection{Geochemical Characteristics}

Gneisses (KA1, NK2, GE2, Ml), amphibolites (NKD1, NKD2) and micaschists (RM, Li); alongside 8 stream sediments with the global fraction (SOP1, VSO1, VSO2,) and rutile concentrate (MBE, and MBA MTC) were assessed for their major, trace and REE.

\subsubsection{Major Elements}

Major elements composition of the analyzed rocks and sediment samples are given in (Table 3). The rocks and sediments exhibit important variations in concentrations of major elements. They are basic to acid with low to high $\mathrm{SiO}_{2}$.

In all the rock types, silica is by quantity the most important major element ranging between $47.56 \mathrm{wt} \% \mathrm{SiO}_{2}$ in amphibolites to $67.18 \mathrm{wt} \% \mathrm{SiO}_{2}$ in gneisses (Table 4), followed by $\mathrm{Al}_{2} \mathrm{O}_{3}$ which varies from one rock type to another according to the rock composition. Average $\mathrm{Al}_{2} \mathrm{O}_{3}$ is $14.98 \mathrm{wt} \%$ in micaschists, 13.53 $\mathrm{wt} \%$ in amphibolite; and $16.88 \mathrm{wt} \%$ in gneisses. $\mathrm{Fe}_{2} \mathrm{O}_{3}$ in gneisses vary from 4.61 to $6.85 \mathrm{wt} \%$, but are of importance in amphibolites with $10.67 \mathrm{wt} \%$ and 11.79 $\mathrm{wt} \%$; while in micaschists the percentage average is $8.10 \mathrm{wt} \%$. $\mathrm{MgO}$ values are low in gneisses and micaschists compared to amphibolites with percentage that range between 4.03 to $4.98 \mathrm{wt} \%$ and 10.64 to $11.87 \mathrm{wt} \%$ respectively. $\mathrm{K}_{2} \mathrm{O}$ is of importance in all the rock types compared to the other alkaline $\mathrm{Na}_{2} \mathrm{O}$ with values that range from 4.53 to $11.15 \mathrm{wt} \%$ and 1.64 to $4.72 \mathrm{wt} \%$ respectively. Gneisses

Table 3. Number of rutile and kyanite Particles and their Weight in the studied area.

\begin{tabular}{cccccc}
\hline \multirow{2}{*}{ Sites } & \multicolumn{2}{c}{$\Phi(\mathrm{mm}) 1-0.125$} \\
\hline \multirow{2}{*}{ Mambando } & Sumples & Rutile & Kyanite & Rutile & Kyanite \\
\hline \multirow{2}{*}{ Nkolmelen } & SOP1 & 90.00 & 32.00 & 1.06 & 0.07 \\
& Nyk2 & 8.00 & 135.00 & 0.04 & 1.85 \\
& NykIIv & 7.00 & 12.00 & 0.01 & 1.7 \\
& Nyk1p & 8.00 & 98.00 & 0.06 & 1.04 \\
Lobo & MBE & 73 & 5 & 0.9 & 1 \\
\hline
\end{tabular}


Table 4. Major element contents (wt\%) of the parent rock and alluvial sediments from Otelé, Matomb and Nguibassal zone.

\begin{tabular}{|c|c|c|c|c|c|c|c|c|c|c|c|c|c|c|}
\hline \multirow{3}{*}{$\begin{array}{l}\text { Chemical } \\
\text { elements }\end{array}$} & \multicolumn{8}{|c|}{ Rocks } & \multicolumn{5}{|c|}{ Sediments } & \multirow{3}{*}{$\begin{array}{c}\text { Concentrate } \\
\text { MTC }\end{array}$} \\
\hline & \multicolumn{4}{|c|}{ Gneiss } & \multicolumn{2}{|c|}{ Amphibolite } & \multicolumn{2}{|c|}{ Micachist } & \multicolumn{5}{|c|}{ Bulk } & \\
\hline & KA1 & NK2 & GE2 & M1 & NKD2 & NKD1 & $\mathrm{RM}$ & $\mathrm{Li}$ & SOP1 & VSO1 & VSO2 & MBE & $\mathrm{MBA}$ & \\
\hline $\mathrm{SiO}_{2}$ & 61.21 & 58.48 & 67.18 & 63.84 & 51.53 & 47.56 & 55.55 & 62.53 & 53.92 & 79.27 & 76.65 & 21.86 & 26.36 & 0.48 \\
\hline $\mathrm{Al}_{2} \mathrm{O}_{3}$ & 17.44 & 18.57 & 14.68 & 16.83 & 13.11 & 13.95 & 14.11 & 15.85 & 13.33 & 7.32 & 7.94 & 3.29 & 2.00 & 0.26 \\
\hline $\mathrm{Fe}_{2} \mathrm{O}_{3}$ & 4.61 & 5.62 & 6.85 & 6.08 & 11.79 & 10.67 & 8.78 & 7.42 & 5.83 & 8.22 & 9.22 & 10.59 & 14.41 & 1.05 \\
\hline $\mathrm{MnO}$ & 0.03 & 0.02 & 0.11 & 0.08 & 0.11 & 0.11 & 0.13 & 0.09 & 0.03 & 0.23 & 0.25 & 0.18 & 0.22 & $<\mathrm{dl}$ \\
\hline $\mathrm{MgO}$ & 4.03 & 4.84 & 2.75 & 2.43 & 11.87 & 10.64 & 4.98 & 3.39 & 0.20 & 1.08 & 1.17 & 0.22 & 0.14 & $<\mathrm{dl}$ \\
\hline $\mathrm{CaO}$ & 1.44 & 1.41 & 1.56 & 0.97 & 0.01 & 0.01 & 2.79 & 1.71 & 0.67 & 0.98 & 1.05 & 0.19 & 0.04 & 0.02 \\
\hline $\mathrm{Na}_{2} \mathrm{O}$ & 4.45 & 3.64 & 2.05 & 1.64 & 1.28 & 1.90 & 4.72 & 1.92 & 0.47 & 0.18 & 0.15 & 0.04 & 0.03 & 0.06 \\
\hline $\mathrm{K}_{2} \mathrm{O}$ & 4.53 & 5.61 & 1.92 & 4.80 & 7.97 & 11.15 & 5.32 & 3.55 & 1.95 & 0.25 & 0.21 & 0.05 & 0.02 & 0.02 \\
\hline $\mathrm{TiO}_{2}$ & 0.93 & 1.15 & 1.42 & 1.19 & 2.01 & 2.84 & 2.91 & 1.53 & 1.19 & 1.17 & 1.79 & 57.65 & 51.77 & 95.03 \\
\hline $\mathrm{P}_{2} \mathrm{O}_{5}$ & 0.16 & 0.16 & 0.06 & 0.17 & 0.29 & 0.37 & 0.50 & 0.28 & 0.21 & 0.07 & 0.08 & 0.05 & 0.04 & 0.01 \\
\hline LOI & 0.63 & 0.79 & 1.17 & 1.37 & 1.41 & 1.03 & 1.03 & 1.70 & 22.56 & 1.34 & 0.40 & $<\mathrm{ld}$ & $<\mathrm{ld}$ & 0.34 \\
\hline $\mathrm{K}_{2} \mathrm{O} / \mathrm{Na}_{2} \mathrm{O}$ & 1.02 & 1.54 & 0.94 & 2.93 & 6.23 & 5.87 & 1.13 & 1.85 & 4.15 & 1.39 & 1.40 & 1.25 & 0.70 & 0.28 \\
\hline Total & 99.46 & 100.29 & 99.75 & 99.40 & 101.38 & 100.23 & 100.82 & 99.97 & 100.36 & 100.11 & 98.91 & 94.49 & 94.44 & 97.28 \\
\hline
\end{tabular}

LOI: Loss on Ignition.

exhibit a percentage of less than $2 \mathrm{wt} \% \mathrm{CaO}$, while its value in micaschists average is $2.25 \mathrm{wt} \%$ and varies between 2.01 and $2.8 \mathrm{wt} \%$ in amphibolites. $\mathrm{MnO}, \mathrm{CaO}$ and $\mathrm{P}_{2} \mathrm{O}_{5}$ are the less abundant elements among the major oxides, ranging between 0.01 and 1.71 wt\% except in micaschists where the value of $\mathrm{CaO}$ is 2.79 $\mathrm{wt} \%$. Average LOI is less than 1 in gneisses and above in amphibolites and micaschists. Micaschists and amphibolites are characterized by the highest contents in $\mathrm{TiO}_{2}$ (greater than $2 \mathrm{wt} \%$ ) except sample $\mathrm{Li}$.

The global fraction of stream sediments chemistry from Otele and Matomb (SOP1, VSO1, and VSO2) equally showed that silica, alumina and iron are the remarkable oxides with average values of $69.95 \mathrm{wt} \%, 9.53 \mathrm{wt} \%$ and $7.76 \mathrm{wt} \%$ respectively (Table 4). The concentrations of the other major oxides are very low (less than $1 \mathrm{wt} \%$ ), except that of $\mathrm{K}_{2} \mathrm{O}$ which is above in the SOP sample and $\mathrm{TiO}_{2}$ which value range from $1.17 \mathrm{wt} \%$ to $1.76 \mathrm{wt} \%$.

Sediment concentrate (MBE, MBA and MTC) exhibit a high concentration of $\mathrm{TiO}_{2}$ with an average value of $68.13 \mathrm{wt} \%$. At Nguibassal, the concentrations in $\mathrm{SiO}_{2}, \mathrm{Al}_{2} \mathrm{O}_{3}$, and $\mathrm{Fe}_{2} \mathrm{O}_{3}$ are higher (with an average value of $24.11 \mathrm{wt} \%, 2.64 \mathrm{wt} \%$ and $12.5 \mathrm{wt} \%$ respectively) compared to the Matomb sample (MTC where they are all below $1.5 \mathrm{wt} \%)$. The other major elements are not of significance (Table 4).

\subsubsection{Trace Elements}

Trace elements of high content in rocks are $\mathrm{Zn}(75-425.63 \mathrm{ppm}), \mathrm{Ba}(369.10$ 1653.99 ppm), Zr (94.48 - 484.5 ppm), Sr (104.76 - 1419.65 ppm) and Rb (66.67 $142.12 \mathrm{ppm}$ ), (Table 5). Chromium values are low, except in micaschists (sample 
Table 5. Trace element composition (ppm) of the parent rock and alluvial sediments from Otelé, Matomb and Nguibassal zone.

\begin{tabular}{|c|c|c|c|c|c|c|c|c|c|c|c|c|c|c|}
\hline \multirow{3}{*}{$\begin{array}{l}\text { Chemical } \\
\text { elements }\end{array}$} & \multicolumn{8}{|c|}{ Rocks } & \multicolumn{5}{|c|}{ Sediments } & \multirow{3}{*}{$\begin{array}{c}\text { Concentrate } \\
\text { MTC }\end{array}$} \\
\hline & \multicolumn{4}{|c|}{ Gneiss } & \multicolumn{2}{|c|}{ Amphibolite } & \multicolumn{2}{|c|}{ Micachist } & \multicolumn{5}{|c|}{ Bulk } & \\
\hline & KA1 & NK2 & GE2 & M1 & NKD2 & NKD1 & $\mathrm{RM}$ & $\mathrm{Li}$ & SOP1 & VSO1 & VSO2 & $\mathrm{MBE}$ & MBA & \\
\hline $\mathrm{Cr}$ & 36.43 & 47.87 & 192 & 131 & 211.09 & 99.18 & 83.46 & 65 & 144.84 & 65 & 76 & 394 & 396 & 444.33 \\
\hline $\mathrm{V}$ & 72.70 & 89.23 & 223.2 & 185.4 & 173.45 & 232.32 & 167.50 & 91.4 & 189.24 & 68.7 & 85.5 & 370 & 370 & 901.33 \\
\hline $\mathrm{Ni}$ & 38.24 & 28.39 & 101.3 & 76.7 & 56.29 & 35.74 & 30.59 & 29.2 & 21.44 & 6.3 & 6.1 & 5.5 & 5.7 & 2.13 \\
\hline $\mathrm{Zn}$ & 104.57 & 425.63 & 132.6 & 125 & 184.99 & 185.49 & 158.47 & 75 & 126.34 & 41 & 43 & 326 & 88 & 7.00 \\
\hline $\mathrm{Cu}$ & 49.59 & 66.91 & 28.2 & 63.4 & 46.28 & 48.01 & 52.44 & 19.5 & 49.64 & 5 & 4.8 & 15 & 58.7 & 1.40 \\
\hline Co & 14.15 & 16.50 & 26.72 & 22.95 & 38.46 & 45.30 & 34.50 & 13.31 & 7.67 & 9.83 & 10.88 & 11 & 10.61 & 0.78 \\
\hline $\mathrm{Ba}$ & 842.35 & 853.93 & 8839 & 1070.5 & 1653.99 & 1540.78 & 958.87 & 369.1 & 481.44 & 70.8 & 56.7 & 22.3 & 8.2 & 4.17 \\
\hline $\mathrm{Zr}$ & 94.48 & 117.80 & 484.5 & 166 & 155.38 & 137.12 & 303.77 & 134 & 213.72 & 144 & 196 & 1450 & 1450 & 66.33 \\
\hline $\mathrm{Sr}$ & 349.28 & 318.74 & 436 & 170 & 104.76 & 132.35 & 1419.65 & 112.6 & 31.82 & 19.9 & 16.7 & 7.3 & 5 & 1.13 \\
\hline $\mathrm{Y}$ & 9.30 & 16.94 & 217.2 & 24.19 & 33.23 & 33.73 & 27.41 & 29.08 & 5.66 & 47.37 & 58.53 & 21.77 & 15.18 & 0.13 \\
\hline $\mathrm{Ga}$ & 20.51 & 20.29 & 19.2 & 21.28 & 23.87 & 22.20 & 24.76 & 15.03 & 21.03 & 5.12 & 5.42 & 4.69 & 2.73 & 1.32 \\
\hline $\mathrm{Pb}$ & 26.85 & 50.16 & 21.95 & 17 & 12.25 & 12.01 & 12.22 & 13.8 & 23.78 & 3.3 & 3.7 & 10.3 & 15 & 2.00 \\
\hline $\mathrm{Rb}$ & 101.92 & 139.55 & 11.13 & 92.57 & 142.12 & 122.13 & 66.67 & 59.73 & 46.74 & 8.25 & 6.78 & 2.21 & 0.83 & 0.48 \\
\hline $\mathrm{Nb}$ & 11.65 & 15.66 & 70.49 & 19.68 & 45.27 & 18.02 & 107.29 & 7.35 & 41.03 & 40.3 & 63.1 & 277 & 277 & 768.33 \\
\hline $\mathrm{Hf}$ & 3.01 & 3.91 & 13.182 & 4.58 & 5.21 & 4.51 & 7.10 & 3.72 & 6.92 & 3.86 & 5.44 & 29 & 29 & 2.81 \\
\hline $\mathrm{U}$ & 1.29 & 2.55 & 1.92 & 1.3 & 1.01 & 0.91 & 2.05 & 1.37 & 2.60 & 2.23 & 4.39 & 14.97 & 11.12 & 7.45 \\
\hline $\mathrm{Ta}$ & 2.62 & 4.55 & 1.92 & 1.25 & 0.56 & 5.67 & 19.87 & 0.54 & 11.31 & 3.08 & 3.05 & 11.86 & 104.31 & 85.89 \\
\hline Cs & 2.05 & 2.08 & 0.48 & 1.22 & 1.37 & 1.18 & 0.83 & 3.02 & 1.28 & 0.35 & 0.29 & 0.1 & 0.07 & 0.02 \\
\hline
\end{tabular}

NKD2) with a value of $211.09 \mathrm{ppm}$. Vanadium values are above $100 \mathrm{ppm}$, except in two gneiss samples (KA1 and NK2) and micaschists (Li). Niobium and Ta contents are significant in sample RM (micaschists) with $107.29 \mathrm{ppm}$ and 19.87 ppm respectively compared to other rock types where their contents are low, 23.51 ppm and $2.44 \mathrm{ppm}$ respectively. Other trace elements have low content.

The global fraction trace elements of high content in the area include: $\mathrm{Zr}$ (144 - $213.73 \mathrm{ppm}), \mathrm{Nb}$ (40.3 - 63.1 ppm), and V (68.7 - $189.24 \mathrm{ppm})$. Otele samples are more enriched in $\mathrm{Cr}, \mathrm{V}, \mathrm{Zn}$ and $\mathrm{Ba}$ with values of $144.84 \mathrm{ppm}, 189.24 \mathrm{ppm}$, $126.34 \mathrm{ppm}$ and $481.44 \mathrm{ppm}$ respectively, compared to the average $70.5 \mathrm{ppm}$, $77.1 \mathrm{ppm}, 42 \mathrm{ppm}$ and $63.75 \mathrm{ppm}$ at Matomb (Table 5).

Rutile concentrate exhibit a high concentration in $\mathrm{Zr}(1450 \mathrm{ppm})$ at Nguibassal while the value is low at Matomb (66.33 ppm). Chromium value is similar at both Matomb and Nguibassal areas ranging between $394 \mathrm{ppm}$ to $444.33 \mathrm{ppm}$ (Table 5). $\mathrm{Zn}$ and $\mathrm{Th}$ are of importance at Nguibassal (average 207 and 45.76 ppm respectively) compared to Matomb (with $7 \mathrm{ppm}$ and $0.24 \mathrm{ppm}$ ). Vanadium 
and $\mathrm{Nb}$ are enriched at Matomb concentrated samples (with values of $901.33 \mathrm{ppm}$ and $768.33 \mathrm{ppm}$ ) compared to Nguibassal (with $370 \mathrm{ppm}$ and $277 \mathrm{ppm}$ ).

\subsubsection{Rare Earth Elements}

The total REE content is very low in all the rocks ranging from 107.12 to 358.36 ppm. They are also enriched in LREE (LREE/HREE 4.71 to $24.58 \mathrm{ppm}$ ) (Table 6). REE with high concentrations are $\mathrm{La}$ (25.01 to $79.48 \mathrm{ppm}$ ), Ce (53.20 to $134.76 \mathrm{ppm}$ ), and $\mathrm{Nd}$ (27.51 to $48.83 \mathrm{ppm}$ ) (Table 6). The chondrite-normalized [14] REE patterns exhibit a strong enrichment in several REE (Table 6, Figure 6 ) and reveal a negative $\mathrm{Eu}$ anomaly ( $\mathrm{Eu} / \mathrm{Eu}^{*}$ ranging between 0.47 to 0.96$)$ and no Ce-anomalies in rocks (Figure 6).

The global fraction total REE varies between 164.34 to $372.26 \mathrm{ppm}$ with an enriched LREE (LREE/HREE 5.09 to 21.30) (Table 6). REE of high concentrations are $\mathrm{La}(33.85-78.88 \mathrm{ppm}), \mathrm{Ce}(67.31$ - $155.2 \mathrm{ppm})$, and $\mathrm{Nd}(28.06-68.69$

Table 6. Rare earth element distribution ( $\mathrm{ppm}$ ) of the parent rock and alluvial sediments from Otelé, Matomb and Nguibassal areas.

\begin{tabular}{|c|c|c|c|c|c|c|c|c|c|c|c|c|c|c|}
\hline \multirow{3}{*}{$\begin{array}{l}\text { Chemical } \\
\text { elements }\end{array}$} & \multicolumn{8}{|c|}{ Rocks } & \multicolumn{5}{|c|}{ Sediments } & \multirow{3}{*}{$\begin{array}{c}\text { Concentrate } \\
\text { MTC }\end{array}$} \\
\hline & \multicolumn{4}{|c|}{ Gneiss } & \multicolumn{2}{|c|}{ Amphibolite } & \multicolumn{2}{|c|}{ Micaschist } & \multicolumn{5}{|c|}{ Bulk } & \\
\hline & KA1 & NK2 & GE2 & M1 & NKD2 & NKD1 & $\mathrm{RM}$ & $\mathrm{Li}$ & SOP1 & VRO1 & VRO2 & MBE & $\mathrm{MBA}$ & \\
\hline $\mathrm{La}$ & 76.95 & 51.41 & 78.1 & 26.17 & 25.01 & 40.15 & 79.48 & 20.57 & 39.45 & 33.85 & 77.88 & 140.36 & 94.88 & 51.09 \\
\hline $\mathrm{Ce}$ & 101.95 & 100.88 & 159.5 & 56.06 & 53.2 & 77.66 & 134.76 & 42.01 & 76.16 & 67.31 & 155.2 & 273.2 & 191.14 & 102.23 \\
\hline $\operatorname{Pr}$ & 13.42 & 11.3 & 18.3 & 6.28 & 6.76 & 8.96 & 13.94 & 4.78 & 8.07 & 7.95 & 18.39 & 31.78 & 22.08 & 41.05 \\
\hline $\mathrm{Nd}$ & 44.15 & 39.84 & 69.61 & 24.6 & 27.51 & 33.93 & 48.83 & 18.07 & 28.06 & 29.62 & 68.59 & 115.72 & 82.67 & 44.64 \\
\hline Sm & 6.03 & 7.09 & 11.62 & 4.9 & 6.14 & 6.71 & 8.32 & 3.53 & 4.53 & 5.49 & 12.08 & 20.65 & 14.67 & 8.02 \\
\hline $\mathrm{Eu}$ & 1.31 & 1.53 & 1.49 & 1.19 & 1.29 & 1.48 & 2.6 & 0.9 & 0.7 & 0.67 & 1.17 & 3.29 & 1.96 & 0.86 \\
\hline Gd & 4.81 & 6.4 & 8 & 4.42 & 6.82 & 7.28 & 8.14 & 3.66 & 3.28 & 5.66 & 9.44 & 12.99 & 8.88 & 6.92 \\
\hline $\mathrm{Tb}$ & 0.5 & 0.84 & 0.88 & 0.7 & 1.03 & 1.09 & 1.07 & 0.72 & 0.32 & 1.15 & 1.56 & 1.15 & 0.8 & 1.24 \\
\hline Dy & 2.41 & 4.6 & 4.59 & 4.4 & 7.08 & 7.3 & 6.58 & 4.99 & 1.62 & 8.24 & 10.44 & 4.48 & 3.24 & 8.49 \\
\hline Ho & 0.34 & 0.65 & 0.85 & 0.87 & 1.28 & 1.31 & 1.06 & 1.04 & 0.26 & 1.76 & 2.21 & 0.79 & 0.56 & 1.80 \\
\hline Er & 0.85 & 1.59 & 2.4 & 2.56 & 3.88 & 3.9 & 2.82 & 3.09 & 0.74 & 5.16 & 6.66 & 2.44 & 1.86 & 5.32 \\
\hline $\mathrm{Tm}$ & 0.13 & 0.24 & 0.34 & 0.39 & 0.65 & 0.63 & 0.44 & 0.45 & 0.13 & 0.76 & 1.01 & 0.41 & 0.34 & 0.80 \\
\hline $\mathrm{Yb}$ & 0.78 & 1.4 & 2.31 & 2.59 & 4.18 & 4.07 & 2.58 & 2.9 & 0.9 & 4.99 & 6.65 & 3.16 & 2.96 & 5.20 \\
\hline $\mathrm{Lu}$ & 0.1 & 0.17 & 0.37 & 0.39 & 0.54 & 0.53 & 0.32 & 0.41 & 0.12 & 0.75 & 0.98 & 0.58 & 0.61 & 0.78 \\
\hline$\Sigma \mathrm{REE}$ & 253.73 & 227.94 & 358.36 & 135.52 & 145.37 & 195.00 & 310.94 & 107.12 & 164.34 & 173.36 & 372.26 & 611 & 427 & 278.44 \\
\hline LREE & 243.81 & 212.05 & 338.62 & 119.20 & 119.91 & 168.89 & 287.93 & 88.96 & 156.97 & 144.89 & 333.31 & 585 & 407 & 247.89 \\
\hline HREE & 9.92 & 15.89 & 19.74 & 16.32 & 25.46 & 26.11 & 23.01 & 17.75 & 7.37 & 28.47 & 38.95 & 26 & 19 & 30.55 \\
\hline LREE/HREE & 24.58 & 13.34 & 17.15 & 7.30 & 4.71 & 6.47 & 12.51 & 5.01 & 21.30 & 5.09 & 8.56 & 22.5 & 21.16 & 8.15 \\
\hline $\mathrm{Ce} / \mathrm{Ce}^{*}$ & 0.77 & 1.01 & 1.02 & 1.05 & 0.99 & 0.99 & 0.98 & 1.02 & 0.98 & 0.95 & 0.95 & 0.93 & 0.97 & 0.95 \\
\hline $\mathrm{Eu} / \mathrm{Eu}^{*}$ & 0.77 & 0.69 & 0.47 & 0.79 & 0.61 & 0.64 & 0.96 & 0.76 & 0.85 & 0.56 & 0.51 & 0.95 & 0.81 & 0.55 \\
\hline
\end{tabular}

$\mathrm{Ce} / \mathrm{Ce}^{*}=\left(\mathrm{Ce}_{\text {sample }} / \mathrm{Ce}\right.$ Chondrite $) /\left(\mathrm{Lasample}_{\text {sachondrite }}\right)^{1 / 2}\left(\mathrm{Pr}_{\text {sample }} / \mathrm{Pr}_{\text {Chondrite }}\right)^{1 / 2} . \mathrm{Eu} / \mathrm{Eu}^{*}=\left(\mathrm{Eu}_{\text {sample }} / \mathrm{Eu}_{\text {Chondrite }}\right) /\left(\mathrm{Sm}_{\text {sample }} / \mathrm{Sm}_{\text {Chondrite }}\right)^{1 / 2}\left(\mathrm{Gd}_{\text {sample }} / \mathrm{Gd}_{\text {Chondrite }}\right)^{1 / 2}$. 
ppm) (Table 6). The Post Archaean Australian Shales (PAAS) normalized REE patterns [15] reveal a negative Eu anomaly and no Ce anomaly in the global fraction (Table 6, Figure 7).

The concentrates showed enrichment in Sm compared to the global fraction with values ranging between 8.02 to $20.65 \mathrm{ppm}$. As for the global fraction, the total REE showed enrichment in LREE/HREE and negative anomalies for Eu and no anomaly in Ce.

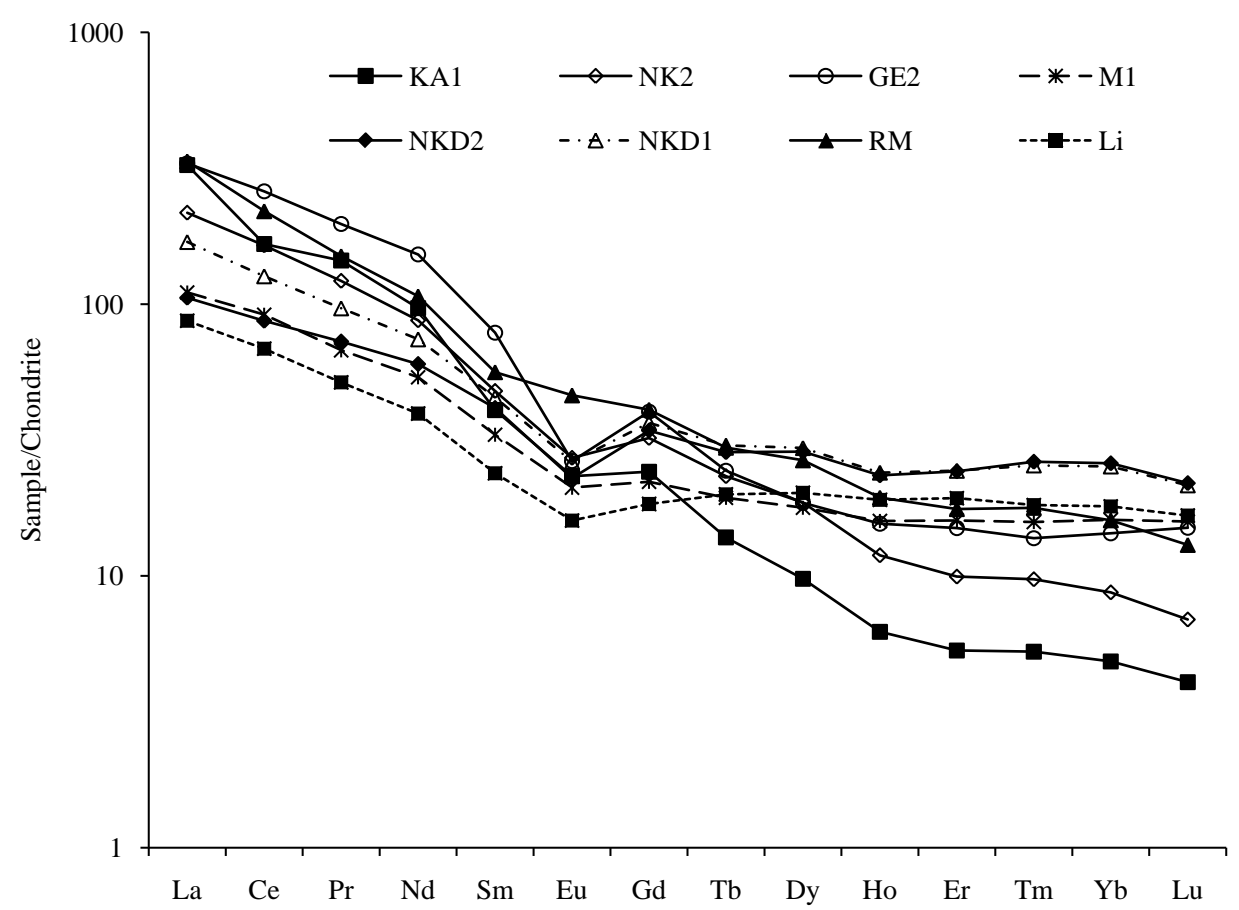

Figure 6. Chondrite normalized REE distribution patterns from the study area [14].

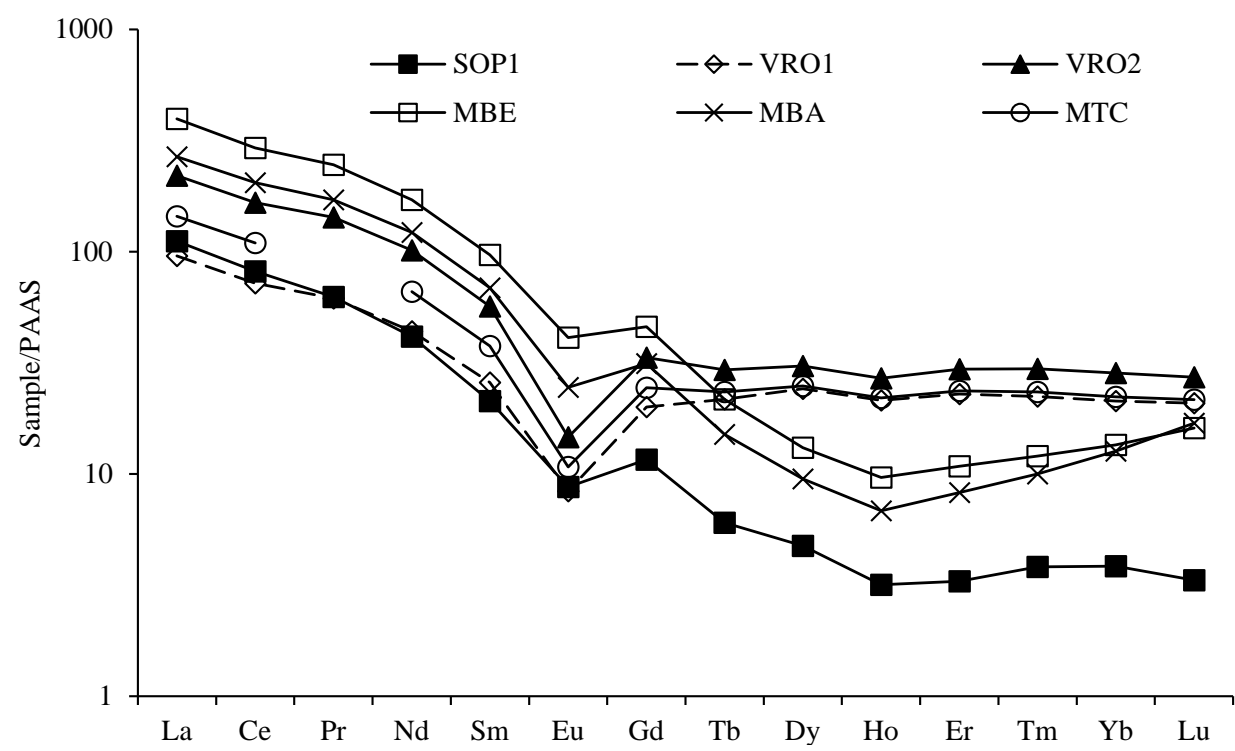

Figure 7. Global fraction and rutile concentrate sediment AAS normalized REE distribution patterns [15]. 


\subsubsection{Matrix of Correlation}

Binary diagram of these elements with other existing elements in rocks showed a positive correlation of $\mathrm{TiO}_{2}$ with $\mathrm{SiO}_{2}, \mathrm{Fe}_{2} \mathrm{O}_{3}, \mathrm{CaO}, \mathrm{Nb}, \mathrm{Ta}$ and $\mathrm{Cr}$ in all the rock types, except with the micaschist sample (RM) from Otele (Figure 8).
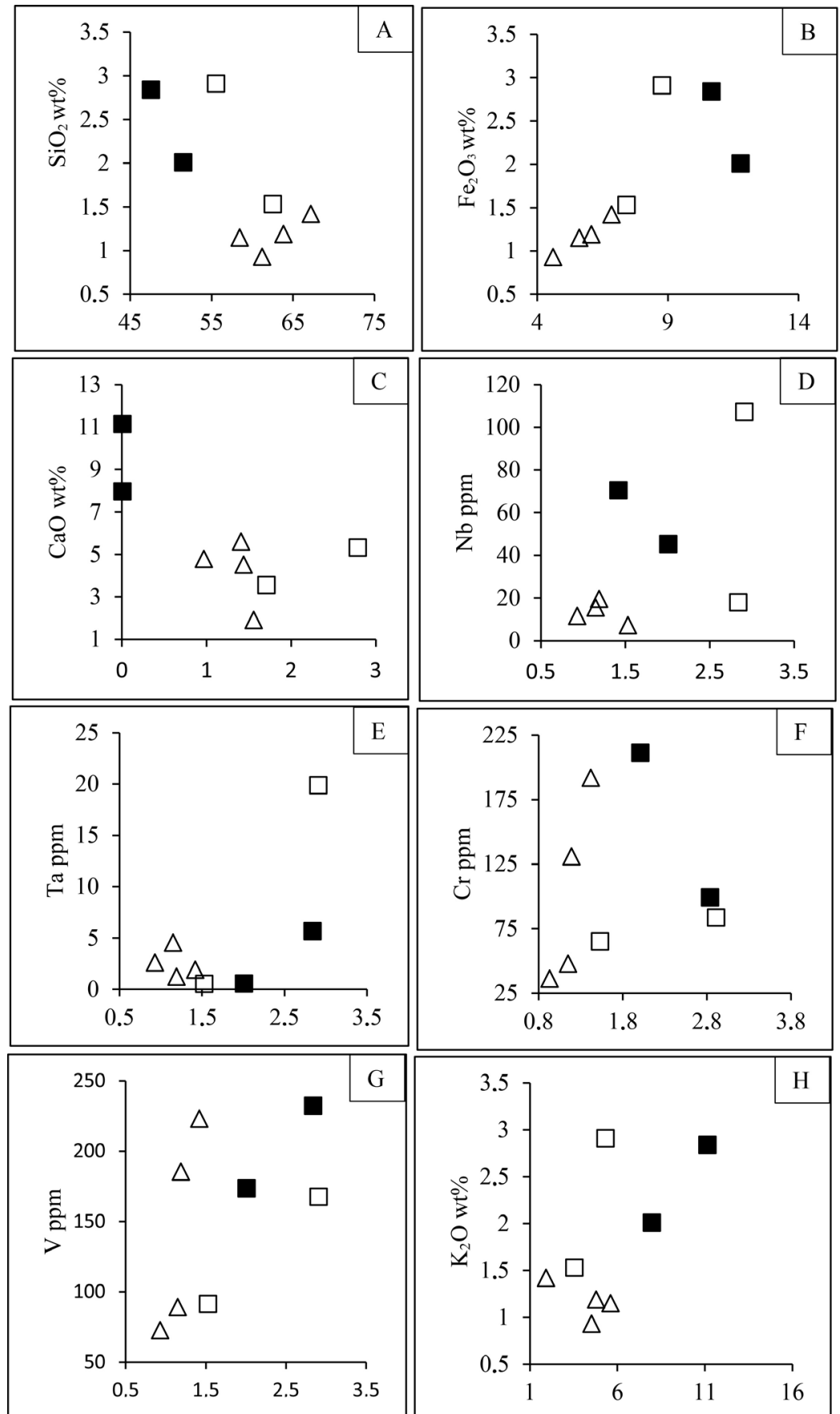

$\mathrm{TiO}_{2} \mathrm{wt} \%$

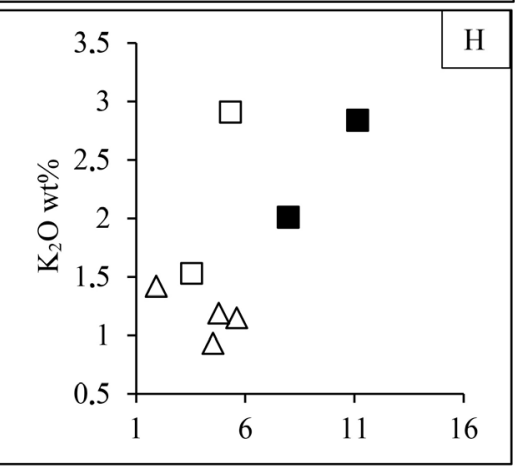

$\triangle$ Gneisses $\square$ Micaschists $\square$ Amphibolites

Figure 8. Binary diagrams of: $\mathrm{TiO}_{2}$ versus some selected major elements for the rocks (A) $\mathrm{SiO}_{2}$ vs $\mathrm{TiO}_{2}$; (B) $\mathrm{Fe}_{2} \mathrm{O}_{3}$ vs $\mathrm{TiO}_{2}$; (C) $\mathrm{CaO}$ vs $\mathrm{TiO}_{2}$; (D) $\mathrm{Nb}$ vs $\mathrm{TiO}_{2}$; (E) Ta vs; $\mathrm{TiO}_{2}$; (F) $\mathrm{Cr}$ vs $\mathrm{TiO}_{2} ;(\mathrm{G}) \mathrm{V}$ vs $\mathrm{TiO}_{2} ;(\mathrm{H}) \mathrm{K}_{2} \mathrm{O}$ vs $\mathrm{TiO}_{2}$. 
$\mathrm{TiO}_{2}$ also shows a positive correlation in both global fraction and concentrate with $\mathrm{SiO}_{2}, \mathrm{Fe}_{2} \mathrm{O}_{3}, \mathrm{CaO}, \mathrm{Nb}$, Ta and $\mathrm{Cr}$; except with the sediment concentrate sample (MTC) from Matomb (Figure 8).

\section{Discussion}

\subsection{Polished Section Interpretation}

Amphibolites were observed in the Otele area with the following mineral composition: $(\mathrm{Amp}+\mathrm{Bt}+\mathrm{Pl}+\mathrm{Kfs}+\mathrm{Qz}+\mathrm{Px}+\mathrm{Grt}+\mathrm{Op})$. Gneisses and micaschists encountered almost have the similar textural and mineral composition and exhibit the following mineral assemblages: gneisses (Fks $+\mathrm{Bt}+\mathrm{Qz}+\mathrm{Ky}+\mathrm{Pl}+$ $\mathrm{Msc}+\mathrm{Grt}+\mathrm{Op})$, and micaschists $(\mathrm{Bt}+\mathrm{Qz}+\mathrm{Msc}+\mathrm{Fks}+\mathrm{Op}+\mathrm{Ky}+\mathrm{Grt})$. These mineral assemblages are similar to those observed in previous works at Matomb and Mandoga area as well as in the Yaoundé Group where they all belong [1] [4] [16] [17]. The difference could come from the temperature and pressure during metamorphism [9].

Regarding the mineral assemblage it is clear that, the primary source of kyanite is gneisses and micaschists. In the Yaoundé Group, mineralization has been tied to come from micaschists and gneisses in both host rock and quartz vein crosscutting the rock. Kyanite phenocrystals observed in micaschists attest this hypothesis [9]. Observed phenol-crystals of kyanite crosscutting micaschists confirm this assertion in quartz veins and in both rocks for the kyanite.

No rutile was observed in thin section. However, previous work attests the presence of rutile in amphibolites, gneisses and micaschists [4] [9] [16] [17]. This absence of rutile may be due to the fact that, the section chosen or the rock did not contain rutile.

\subsection{Sedimentological Analyses and the Origin of the Mineralization}

Angular shaped rutile and kyanite were observed in stream sediments. This presence of prismatic crystals of rutile and kyanite is indicative that these sediments come from surrounding rocks [18]. The angular shape of the majority of the grains of rutile, kyanite and quartz indicates immature sediment. These sediments are homometric well sorted and well classified.

Morphological statistics of sediments from the three locations (Otele, Matomb, Nguibassal) of the study area reveal a very low proportions of shiny blunt grains (8.15\%); low sub-blunt grains (19.87\%), and a clear dominance of unworn grains (64.62\%). Unworn grains of rutile, kyanite and quartz observed in these locations are the most abundant $(\sim 65 \%)$ and are thought to result from short transport. It is known that, shiny dulls grains are characteristic of constant reworking or long transport in fluviatile environments, sub-rounded are characteristic of a relatively long hydromechanics transport, while the less abundant sub-blunt kernels have undergone slight shaping during transport by river waters [19] [20]. The polished appearance of the edges of these grains is caused by the phenomenon of collision between the grains during transport, stream bed 
attrition and abrasion. Moreover, unworn grains are the result of local sedimentation. Their abundance is linked to a short transportation and deposition [21]. This high percentage of unworn sediment therefore showed that the mineralization is found in location surrounding the area of deposition and therefore orientated primary search of kyanite and rutile toward rocks that are close to this area. Thus, the sediment morphological features are inherited from the sources rocks and marked a very low sedimentary process modification in a proximal source [22]. Therefore, on the basis of quartz, kyanite and rutile sediments morphology, it clearly appears that, the sediments exhibit two origins: 1) a local sedimentation with grains which retained their original shape; and 2) sediments deposited reworked by phenomenon of collision between the grains during transport, stream bed attrition and abrasion.

\subsection{Geochemistry and Exploration}

Provenance characteristics of clastic sediments can be deduced using various approaches based on the geochemical data. These are discussed below.

\subsubsection{Major Elements}

Major elements analysis showed that $\mathrm{SiO}_{2}, \mathrm{Al}_{2} \mathrm{O}_{3}, \mathrm{Fe}_{2} \mathrm{O}_{3}$ are the main elements in both rocks and the sediments global fraction. The high content in $\mathrm{SiO}_{2}$ associated to the low $\mathrm{MgO}$ may suggest a felsic protolith [18] [23].

$\mathrm{TiO}_{2}$ percentage in both rocks and the global fraction of sediments is similar and a drastic increase is observed in the sediment concentrate. This may suggest that the $\mathrm{TiO}_{2}$ percentage encountered in minerals of the global fraction to come from the same minerals in the rock, and this percentage increases in the sediment concentrate due to panning of the fraction. It has been demonstrated that, high concentration in $\mathrm{TiO}_{2}$ generally marks the presence of Ti rich mineral such as rutile and brookite [4]. Therefore, the high $\mathrm{TiO}_{2}$ support the presence of these two minerals in these areas. Heavy mineral association in sediments highlights the presence of these two minerals. The presence of elevated $\mathrm{TiO}_{2}$ in sediments is suggested to be related to the presence of rutile in the alluvium [9] [24] [25]. This therefore suggests the element to come from rutile or brookite in rocks. The less abundant brookite in sediments instead suggests the Ti percentage to mainly come from rutile.

Moreover, $\mathrm{TiO}_{2}$ and $\mathrm{SiO}_{2}$ positive correlation is indicative of the presence of rutile [4]. However, the high $\mathrm{SiO}_{2}$ observed in the concentrate at Nguibassal is linked to the proportion of quartz. The positive correlation between $\mathrm{TiO}_{2}$ and $\mathrm{Fe}_{2} \mathrm{O}_{3}$, $\mathrm{CaO}, \mathrm{Nb}, \mathrm{Ta}$ and $\mathrm{Cr}$ reveal that these elements might be found in the same bearer-mineral in these rocks.

$\mathrm{Al}_{2} \mathrm{O}_{3}$ and $\mathrm{MgO}$ permit to distinguished rutile from crustal and mantle source [26]. $\mathrm{Mg}$ and $\mathrm{Al}$ rich rutile are most likely derived from mantle rocks [27]. The absence of $\mathrm{MgO}$ and low $\mathrm{Al}_{2} \mathrm{O}_{3}$ in the rutile concentrate suggested rutile comes from a crustal source.

$\mathrm{Na}_{2} \mathrm{O} \mathrm{CaO}$ and $\mathrm{MgO}$ are of low importance in gneisses and micaschists, and 
are very low to absent in both global fraction and rutile concentrate. The progressive reduction of $\mathrm{Na}_{2} \mathrm{O}$ and $\mathrm{CaO}$ in sediments is also due to the weathering of plagioclase [28]. The correlation matrix of $\mathrm{CaO}$ with $\mathrm{TiO}_{2}$ is positive and suggests that the elements to be present in rutile in a very low amount as suggested by the chemistry of the global fraction and rutile concentrate of Matomb. In addition, the low concentration of $\mathrm{MgO}$ in sediments and high in all the rocks types (Table 4) suggests $\mathrm{Mg}$ to come from amphibolite or garnet in rocks as reported in previous works [29].

\subsubsection{Trace Elements}

Investigated rocks and sediments showed variability in the enrichment of trace elements. Barium, $\mathrm{Ni}, \mathrm{Sr}$, and $\mathrm{Cu}$ exhibit high concentrations in rocks and low concentrations in sediments as compared to $\mathrm{Cr}, \mathrm{Nb}, \mathrm{V} \mathrm{Zr}$, and Ta. Enrichment of these elements might suggest two different sources of rutile. Previous studies suggested sediment deriving from felsic rock weathering in the crust to be rich in $\mathrm{Zr}, \mathrm{La}, \mathrm{Th}, \mathrm{Rb}$ and $\mathrm{Sr}$, while those enriched in $\mathrm{Cr}, \mathrm{Co}, \mathrm{Sc}, \mathrm{Ni}$, and $\mathrm{V}$ derive from mafic rocks [30].

Alluvial rutile of the concentrate is characterized by high $\mathrm{Nb}$ contents (277 $768.33 \mathrm{ppm})$ as compared to $\mathrm{Cr}(394-444.33 \mathrm{ppm})$, elements that are considered as major discriminant in the determination of sources rock [31]. It is suggested that, concentration of $\mathrm{Cr}$ is low as compared to that of $\mathrm{Nb}$ in felsic rocks (micaschists and gneisses) [32]. Field observations confirm the presence of these rocks. Moreover [33] diagram confirm the felsic sources of rutile concentrate (Figure 9). However, sample MBA showed enrichment in $\mathrm{Cr}$ as compared to $\mathrm{Nb}$

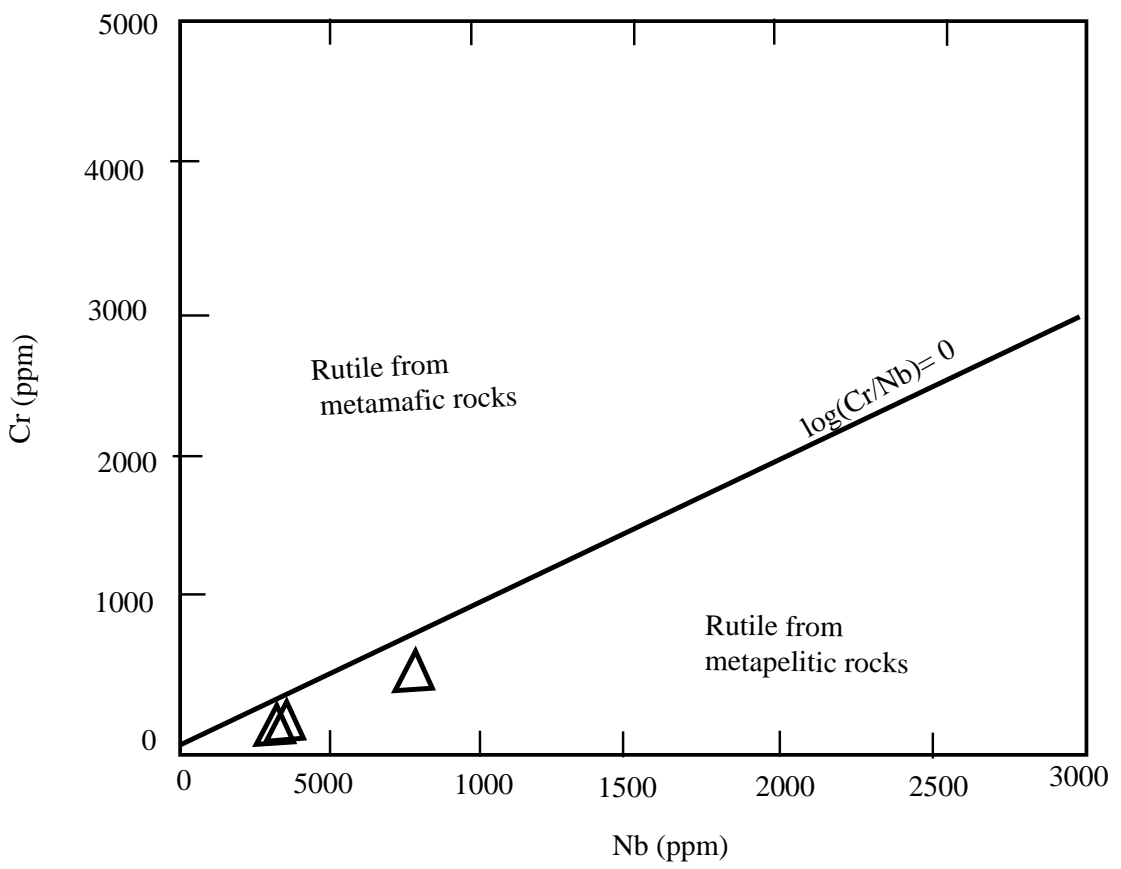

Figure 9. $\mathrm{Nb}$ vs. Cr discrimination diagrams for rutile from different metamorphic lithologies according to Triebold et al. (2007). Positive $\log (\mathrm{Cr} / \mathrm{Nb})$ values mostly indicate a metamafic source for rutile while negative values suggest derivation from metapelitic rocks. 
suggesting another source for rutile. Rutile from mafic origin is rich in $\mathrm{Cr}$ and poor in $\mathrm{Nb}$ [32] [34]. This therefore suggested that rutile found come from the same area but with several source rocks and $\mathrm{Cr}$ to be present as trace impurities.

The high to moderate concentration in $\mathrm{Cr}, \mathrm{V}, \mathrm{Mn}, \mathrm{Fe}, \mathrm{Mg}, \mathrm{Ni}$, and $\mathrm{Co}$ are due to the presence of ferromagnesian minerals in metamorphic rocks such as amphibole, garnet, chlorite, as well as rutile and kyanite [29] [35]. High concentrations in $\mathrm{Cr}$ (>150 ppm) were observed in sediments and in one amphibolite sample. This could suggest an ultramafic source rock [36]. Thus, rutile may come from amphibolite. Moreover, a high concentration in $\mathrm{Nb}$ instead suggests a mafic felsic and therefore originated from micaschists.

Correlation matrix showed a positive correlation between $\mathrm{TiO}_{2}$ and $\mathrm{V}, \mathrm{Nb}, \mathrm{Ta}$ and $\mathrm{CaO}$. The good correlation between $\mathrm{TiO}_{2}$ and these four elements confirms that, rutile contains a series of trace elements

The $\mathrm{Zr}$ percentage observed at Matomb concentrate $66.33 \mathrm{ppm}$ is practically similar to values of alluvial zircon of the Yaoundé Group (91 ppm, [37]. Zr enrichment in the rutile lattice have been demonstrated by several authors [38] [39]. The high content of $\mathrm{Zr}$ at Nguibassal concentrate (>1000 ppm) remain questionable. Enrichment in $\mathrm{Zr}$ could be justified by the abundance of zirconium as observed in heavy mineral concentrate and thus part of the rutile lattice.

The high contents of $\mathrm{Rb}, \mathrm{Ba}$ and $\mathrm{Sr}$ in rocks and sediments may be due to the presence of minerals such as muscovite and feldspars. It has been demonstrated that $\mathrm{K}$-feldspars contains $\mathrm{Rb}, \mathrm{Ba}$ while $\mathrm{Sr}$ is concentrated in plagioclase [40]. The reduction of $\mathrm{Sr}$ and $\mathrm{Ba}$ from rocks to global fraction and sediments concentrates is due to the weathering of plagioclase [29] [41] or to the recrystallisation of clay minerals [29].

\subsubsection{Rare Earth Elements}

The similarity of REE behavior in rocks and sediments explains the complexation of REE in solution during weathering [25]. Stream sediments geochemistry normalized with PAAS showed enrichment in LREE/HREE and a negative Eu anomaly. Previous works clearly showed that, REE normalization with negative $\mathrm{Eu}$ anomalies generally permits to understand the origin of terrigenous sediments [4] [42] [43]. These negative Eu anomalies in sediments derived from felsic rocks [44]. Elevated ratio of LREE/HREE coupled to the negative Eu anomalies in rocks and sediments is indicative of felsic source material that contained the mineralization [18] [23]. Again, it has been observed that, REE of Matomb, Mandoga and Yaoundé showed similar behavior with a negative Eu anomalies and enrichment in LREE [18] [45]. This suggests a unique source of sediments [18] [45]. However, recent data obtained in the Yaoundé Group suggested a pegmatitic source in the area [37].

\section{Conclusions}

They studied rocks that are characterized by a similar mineralogical pattern. Sedimentological analyses reveal the dominance of unworn grains of rutile quartz 
and kyanite. Silica is the most important major element. Sediment chemistry shows that silica and alumina are the notable elements with a high concentration of $\mathrm{TiO}_{2}$. The main conclusions are as follows:

1) Three rock types were encountered in the field: gneisses (Fks $+\mathrm{Bt}+\mathrm{Qz}+$ $\mathrm{Ky}+\mathrm{Pl}+\mathrm{Msc}+\mathrm{Grt}+\mathrm{Op})$, micaschists $(\mathrm{Bt}+\mathrm{Qz}+\mathrm{Msc}+\mathrm{Fks}+\mathrm{Op}+\mathrm{Ky}+\mathrm{Grt})$ and amphibolites (Amp $+\mathrm{Bt}+\mathrm{Pl}+\mathrm{Kfs}+\mathrm{Qz}+\mathrm{Px}+\mathrm{Grt}+\mathrm{Op})$.

2) Morphological shapes with the high percentage of unworn sediments from the three locations (Otele, Matomb, Nguibassal) showed that, they are inherited from the source rocks and marked a very low sedimentary process modification in a proximal source.

3) Sediments exhibit two origins: 1) a local sedimentation with grains which retained their original shape; and 2) sediments deposited reworked by phenomenon of collision between the grains during transport, stream bed attrition and abrasion.

4) $\mathrm{TiO}_{2}$ percentage encountered in minerals of the global fraction and rutile concentrate come from the same minerals in the rock, and percentage increases associated to heavy minerals observation suggested the Ti percentage to mainly come from rutile.

5) Rutile was found to come from the same area originating from several source rocks.

\section{Conflicts of Interest}

The authors declare no conflicts of interest regarding the publication of this paper.

\section{References}

[1] Stendal, H., Toteu, S.F., Frei, R., Penaye, J., Njel, U.O., Bassahak, J., Nni, J., Kankeu, B., Ngako, V. and Hell, J.V. (2006) Derivation of Detrital Rutile in the Yaoundé Region from the Neoproterozoic Pan-African Belt in Southern Cameroon (Central Africa). Journal of African Earth Sciences, 44, 443-456. https://doi.org/10.1016/j.jafrearsci.2005.11.012

[2] Bolfa, J., Chevallier, R., De La Roche, H. and Kern, R. (1961) Contribution à l'étude des ilmenitees du sud-est de Madagascar et du Sénégal. Relations avec la nature de l'arizonite. Bulletin de la Société Française de Minéralogie et de la Cristallographie, 4, 357-473. https://doi.org/10.3406/bulmi.1961.5447

[3] Dumon, J.C. (1981) Comportement du titane dans les phénomènes d'altération et de sedimentation sous differents climats. Esquisse d'un cycle biogéochimique. Thèse de Doctorat d'Etat es-Sciences, Universite de Bordeaux I, Bordeaux, 296 p.

[4] Mbanga Nyobe, J., Sababa, E., Bayiga, E.C. and Ndjigui, P.D. (2018) Mineralogical and Geochemical Features of Alluvial Sediments from the Lobo Watershed (Southern Cameroon): Implications for Rutile Exploration. Comptes Rendus Geoscience, 350, 119-129. https://doi.org/10.1016/j.crte.2017.08.003

[5] Ngon Ngon, G.P. (1996) Etude de la genèse des dépôts de rutile alluvionnaire du Cameroun: Le cas des dépôts de rutile alluvionnaires du bassin versant de la Messié Mezoa. Département de la Mefou-et-Akono, province du Centre, Mém, Maît, Univ, 
Ydé I, 71 p.

[6] Olivry, J.C. (1986) Fleuves et rivières du Cameroun. Monographies hydrologiques. MESRES-ORSTOM, Paris, 733 p.

[7] Toteu, S.F., Van Schmus, W.R., Penaye, J. and Michard, A. (2001) New U-Pb and Sm-Nd Data from North-Central Cameroon and Its Bearing on the Pre-Pan African History of Central Africa. Precambrian Research, 108, 45-73. https://doi.org/10.1016/S0301-9268(00)00149-2

[8] Owona, S., Shulz, B., Ratschbacher, L., Mvondo Ondoa, J., Ekodeck, G.E., Tchoua, F.M. and Affaton, P. (2011) Pan-African Metamorphic Evolution in the Southern Yaoundé Group (Oubanguide Complex, Cameroon) as Revealed by EMP-Monazite Dating and Thermobarometry of Garnet Metapelites. Journal of African Earth Sciences, 59, 125-139. https://doi.org/10.1016/j.jafrearsci.2010.09.003

[9] Maurizot, P., Abessolo, A., Feybesse, A., Johan, V. and Lecomte, P. (1986) Etude et prospection minière du Sud-Ouest Cameroun. Synthèse des travaux de 1978 à 1985. 85-CMR 066 BRGM.

[10] Pauwels, S.J., Ranst, E., Verlo, M. and Mvondo, A. (1992) Manuel de laboratoire de géologie, méthodes d'analyses des sols et des plantes, équipements, gestion des stocks et des produits chimiques. Publications agricoles, $\mathrm{n}^{\circ} 26,265 \mathrm{p}$.

[11] Mathieu, C. and Pileltain, F. (1998) Analyse physique des sols. Masson, 274 p.

[12] Fuchtbeur. (1959) Caractérisation des sables de l'eau de la Dibamba (de Japoma à Massombou), Douala Cameroun: Évaluation de la Dynamique marine. Mém D.E.A. Université de Yaoundé 1, 80 p. Universite de Yaounde creee en 1967.

[13] Chamley, H. (1987) Sédimentologie. Ed. Dunod, collection géosciences, 175 p.

[14] McDonough, W.F. and Sun, S.S. (1995) The Composition of the Earth. Chemical Geology, 120, 223-253. https://doi.org/10.1016/0009-2541(94)00140-4

[15] Taylor, S.R. and McLennan, S.M. (1985) The Continental Crust: Its Composition and Evolution. Blackwell Scientific, Oxford, 312 p.

[16] Tonje, J.C., Ndjigui, P.D., Nyeck, B. and Bilong, P. (2014) Geochemical Features of the Matomb Alluvial Rutile from the Neoproterozoic Pan-African Belt, Southern Cameroon. Chemie der Erde, 74, 557-570.

https://doi.org/10.1016/j.chemer.2013.09.002

[17] Metang, V. (2015) Cartographie géologique du secteur de Matomb-Makak (centresud Cameroun). Implication sur l'évolution géodynamique du groupe panafricain de Yaoundé. Thèse de Doctorat $\mathrm{Ph} / \mathrm{D}$, Université de Yaoundé 1, Yaoundé, 263 p.

[18] Bassis, A., Hinderer, M. and Meinhold, G. (2016) New Insights into the Provenance of Saudi Arabian Palaeozoic Sandstones from Heavy Mineral Analysis and Single-Grain Geochemistry. Sedimentary Geology, 333, 100-114. https://doi.org/10.1016/j.sedgeo.2015.12.009

[19] Cailleux A. (1942) Distinction des sables marins et fluviatiles. Bulletin de la société géologique de France. S5-XIII (4-6), 125-138. https://doi.org/10.2113/gssgfbull.S5-XIII.4-6.125

[20] Kanouo, S.N., Yongue-Fouateu, R., Chen, S., Njonfang, E., Ma, C., Ghogomu, R.T., Zhao, J. and Sababa, E. (2012) Greyish-Black Megaclasts from the Nsanaragati Gem Placer, SW Cameroon: Geochemical Features and Genesis. Journal of Geography and Geology, 4, 134-146. https://doi.org/10.5539/jgg.v4n2p134

[21] Dumouchel, J. (1995) Exploration Report on Cameroun Alluvial Rutile Reconnaissance March 15-April 11, 1995. QIT-FER et titane INC, $12 \mathrm{p}$.

[22] Dill, H.G. (2007) Grain Morphology of Heavy Minerals from Marine and Continental 
Placer Deposits, with Special Reference to Fe-Ti Oxides. Sedimentary Geology, 198, 1-27. https://doi.org/10.1016/j.sedgeo.2006.11.002

[23] Silva, M.V.M.G., Pinto, M.M.S.C. and Carvalho, P.C.S. (2016) MAJOR, Trace and REE Geochemistry of Recent Sediments from Lower Catumbela River (Angola). Journal of African Earth Sciences, 115, 203-217. https://doi.org/10.1016/j.jafrearsci.2015.12.014

[24] Nesbitt, H.W. and Young, G.M. (1984) Prediction of Some Weathering Trends of Plutonic and Volcanic Rocks Based on Thermodynamic and Kinetic Considerations. Geochemica et Cosmochimica Acta, 48, 1523-1534. https://doi.org/10.1016/0016-7037(84)90408-3

[25] Nzenti, J.P., Barbey, P., Macaudiere, J. and Soba, D. (1988) Origin and Evolution of the Precambrian High Grade Yaoundé Gneisses (Cameroon). Precambrian Research, 38, 91-109. https://doi.org/10.1016/0301-9268(88)90086-1

[26] Smythe, D.J., Schulze, D.J. and Brenan, J.M. (2008) Rutile as a Kimberlite Indicator Mineral: Minor and Trace Element Geochemistry. 9th International Kimberlite Conference, Extended Abstract, No. 9IKC-A-00193.

https://doi.org/10.29173/ikc3434

[27] Sobolev, N.V. and Yefimova, E.S. (2000) Composition and Petrogenesis of Ti-Oxides Associated with Diamonds. International Geology Review, 42, 758-767. https://doi.org/10.1080/00206810009465110

[28] Nyakairu, G.W.A. and Koeberl, C. (2001) Mineralogical and Chemical Composition and Distribution of Rare Earth Elements in Clay-Rich Sediments from Central Uganda. Geochemical Journal, 35, 13-28. https://doi.org/10.2343/geochemj.35.13

[29] Alchin, D., Lickfold, V., Mienie, P.J., Nel, D. and Strydom, M. (2008) An Integrated Exploration Approach to the Sishen South Iron Ore Deposit Northern Cape Province, South Africa, and Its Implication for Developing a Structural and/or Resource Model for These Deposits. Reviews in Economic Geology, 15, 317-338. https://doi.org/10.5382/Rev.15.12

[30] Wronkiewicz, D.J. and Condie, K.C. (1990) Geochemistry and Mineralogy of Sediments from the Ventersdorp and Transvaal Supergroups, South Africa: Cratonic Evolution during the Early Proterozoic. Geochimica et Cosmochimica Acta, 54, 343-354. https://doi.org/10.1016/0016-7037(90)90323-D

[31] Meinhold, G. (2010) Rutile and Its Application in Earth Sciences. Earth Sciences Review, 102, 1-28. https://doi.org/10.1016/j.earscirev.2010.06.001

[32] Zack, T., von Eynatten, H. and Kronz, A. (2004) Rutile Geochemistry and Its Potential Use in Quantitative Provenance Studies. Sedimentary Geology, 171, 37-58. https://doi.org/10.1016/j.sedgeo.2004.05.009

[33] Triebold, S., von Eynatten, H., Luvizotto, G.L. and Zack, T. (2007) Deducing Source Rock Lithology from Detrital Rutile Geochemistry: An Example from the Erzgebirge, Germany. Chemical Geology, 244, 421-436.

https://doi.org/10.1016/j.chemgeo.2007.06.033

[34] Meyer, M., John, T., Brandt, S. and Klemd, R. (2011) Trace Element Composition of Rutile and the Explanation of Zr in Rutile Thermometry to UHT Metamorphism (Epupa Complex, NW Namibia). Lithos, 126, 388-401. https://doi.org/10.1016/j.lithos.2011.07.013

[35] Lesher, C.M. and Stone, W.E. (1996) Exploration Geochemistry of Komatiites. In: Wyman, D.A., Ed., Igneous Trace Elements Geochemistry, Application for Massive Sulphide Exploration, Geological Association of Canada, Short Course Notes, St. John's, Vol. 12, 153-204. 
[36] Garver, J.I., Royce, P.R. and Smick, T.A. (1996) Chromium and Nickel in Shale of the Taconic Foreland: A Case Study for the Provenance of Fine-Grained Sediments with an Ultramafic Source. Journal of Sedimentary Research, 66, 100-106. https://doi.org/10.1306/D42682C5-2B26-11D7-8648000102C1865D

[37] Ngo Bidjeck Bondje, L.M., Bineli Betsi, T., Nga Mama, L.N., Ngo Belnoun, R.N., Molotouala, A.C., McFarlane, C. and Bitom, D.L. (2020) Geochemistry of Rutile from the Pan-African Yaounde Metamorphic Group: Implication for Provenance and Conditions of Formation. Journal of African Earth Sciences, 170, 103-912. https://doi.org/10.1016/j.jafrearsci.2020.103912

[38] Luvizotto, G.L. and Zack, T. (2009) Nb and Zr Behavior in Rutile during High-Grade Metamorphism and Retrogression: An Example from the Ivrea Verbano Zone. Chemical Geology, 261, 303-317. https://doi.org/10.1016/j.chemgeo.2008.07.023

[39] Spear, F.S., Wark, D.A., Cheney, J.T., Schumacher, J.C. and Watson, B. (2006) Zr-inRutile Thermometry in Blueschists from Sifnos, Greece. Contributions to Mineralogy and Petrology, 152, 375-385. https://doi.org/10.1007/s00410-006-0113-4

[40] White, W.M. (2013) Geochemistry. Wiley-Blackwell, Amsterdam, 660 p.

[41] Augustsson, C. and Bahlburg, H. (2003) Active or Passive Continental Margin. Geochemical and Nd Isotope Constraints of Metasediments in the Backstop of a PreAndean Accretionary Wedge in South Chile (46 $\left.30^{\prime}-48^{\circ} 30^{\prime}\right)$. In: McCann, T. and Saintot, A., Eds., Tracing Tectonic Deformation Using the Sediment Record, Geological Society London Special Publication 208, London, 253-268. https://doi.org/10.1144/GSL.SP.2003.208.01.12

[42] Nagarajan, R., Madhavaraju, J., Armstrong-Altrin, J.S. and Nagendra, R. (2011) Geochemistry of Neoproterozoiclimestones of Shahabad Formation, Bhima Basin, Karnataka, Southern India. Geosciences Journal, 15, 9-25.

https://doi.org/10.1007/s12303-011-0005-0

[43] Ali, S., Stattegger, K., Garbe-Schöngerg, D., Frank, M., Kraft, S. and Kuhnt, W. (2014) The Provenance of Cretaceous to Quaternary Sediments in the Tarfaya Basin, SW Morocco: Evidence from Trace Element Geochemistry and Radiogenic Nd-Sr Isotopes. Journal of African Earth Sciences, 90, 64-76. https://doi.org/10.1016/j.jafrearsci.2013.11.010

[44] Cullers, R.L., Barrett, T., Carlson, R. and Robinson, B. (1987) Rare Earth Element and Mineralogic Changes in Holocene Soil and Stream Sediment: A Case Study in the Wet Mountains, Colorado, USA. Chemical Geology, 63, 275-297. https://doi.org/10.1016/0009-2541(87)90167-7

[45] Nyeck, B., Ngimbous, R.V. and Ndjigui, P.-D. (2019) Petrology of Saprolite Developed on Gneisses in the Matomb Region, South Cameroon. Journal of African Earth Sciences, 150, 107-122. https://doi.org/10.1016/j.jafrearsci.2018.10.017 